\title{
Mid-Wisconsin to Holocene Permafrost and Landscape Dynamics based on a Drained Lake Basin Core from the Northern Seward Peninsula, Northwest Alaska
}

\author{
Josefine Lenz, ${ }^{1,2 *}$ Guido Grosse, ${ }^{1}$ Benjamin M. Jones, ${ }^{3}$ Katey M. Walter Anthony, ${ }^{4}$ Anatoly Bobrov, ${ }^{5}$ Sabine Wulf ${ }^{6}$ \\ and Sebastian Wetterich ${ }^{1}$ \\ ${ }^{1}$ Department of Periglacial Research, Alfred Wegener Institute, Helmholtz Centre for Polar and Marine Research, Potsdam, Germany \\ 2 Institute for Earth and Environmental Sciences, University of Potsdam, Potsdam, Germany \\ 3 Alaska Science Center, US Geological Survey, Anchorage, AK, USA \\ ${ }^{4}$ Water and Environmental Research Center, University of Alaska, Fairbanks, AK, USA \\ 5 Faculty of Soil Science, Lomonosov Moscow State University, Moscow, Russia \\ ${ }^{6}$ Section 5.2 Climate Dynamics and Landscape Evolution, Helmholtz-Centre Potsdam, GFZ German Research Centre for Geosciences, \\ Potsdam, Germany
}

\begin{abstract}
Permafrost-related processes drive regional landscape dynamics in the Arctic terrestrial system. A better understanding of past periods indicative of permafrost degradation and aggradation is important for predicting the future response of Arctic landscapes to climate change. Here, we used a multi-proxy approach to analyse a $\sim 4 \mathrm{~m}$ long sediment core from a drained thermokarst lake basin on the northern Seward Peninsula in western Arctic Alaska (USA). Sedimentological, biogeochemical, geochronological, micropalaeontological (ostracoda, testate amoebae) and tephra analyses were used to determine the long-term environmental Early-Wisconsin to Holocene history preserved in our core for central Beringia. Yedoma accumulation dominated throughout the Early to Late-Wisconsin but was interrupted by wetland formation from 44.5 to $41.5 \mathrm{ka}$ BP. The latter was terminated by the deposition of $1 \mathrm{~m}$ of volcanic tephra, most likely originating from the South Killeak Maar eruption at about $42 \mathrm{ka}$ BP. Yedoma deposition continued until $22.5 \mathrm{ka} \mathrm{BP}$ and was followed by a depositional hiatus in the sediment core between 22.5 and $0.23 \mathrm{ka} \mathrm{BP}$. We interpret this hiatus as due to intense thermokarst activity in the areas surrounding the site, which served as a sediment source during the Late-Wisconsin to Holocene climate transition. The lake forming the modern basin on the upland initiated around $0.23 \mathrm{ka} \mathrm{BP}$ and drained catastrophically in spring 2005 . The present study emphasises that Arctic lake systems and periglacial landscapes are highly dynamic and that permafrost formation as well as degradation in central Beringia was controlled by regional to global climate patterns as well as by local disturbances. Copyright (C) 2015 John Wiley \& Sons, Ltd.
\end{abstract}

KEY WORDS: Beringia; palaeoenvironmental reconstruction; thermokarst lake dynamics; cryostratigraphy; tephra; bioindicators; yedoma

\section{INTRODUCTION}

Climate change has a significant impact on the Arctic terrestrial system (Hinzman et al., 2005). Warming and thawing of permafrost has been observed for several decades (Romanovsky et al., 2007, 2010; Grosse et al., 2011; Vaughan et al., 2013) and inferred from numerous palaeoecological studies (Mann et al., 2002; Kaufman

* Correspondence to: J. Lenz, Department of Periglacial Research, Alfred Wegener Institute, Helmholtz Centre for Polar and Marine Research, Potsdam, Telegrafenberg A43, 14473 Potsdam, Germany. E-mail: Josefine.Lenz@awi.de et al., 2004; Gaglioti et al., 2014). The degradation of permafrost-dominated landscapes influences hydrology, ecology, ground thermal regime and biogeochemical cycles (Rowland et al., 2010; Grosse et al., 2013a; Walter Anthony et al., 2014). Thermokarst lakes represent a particularly widespread mode of permafrost degradation (Jorgenson et al., 2006) and dominate Arctic lowlands in Siberia, Alaska and northwest Canada. They cover up to $40 \%$ (Smith et al., 2007; Grosse et al., 2013a) and drained lake basins up to $70 \%$ (Walter Anthony et al., 2014) of the landscape's surface in some of these lowlands. Thermokarst lakes form by thawing of ice-rich permafrost or melting of massive ground ice followed by ground settlement (Van 
Everdingen, 2005). After their initiation as small shallow ponds, these lakes typically experience a succession of growth, shrinkage and gradual or even sudden drainage (Burn and Smith, 1990; Jorgenson and Shur, 2007; Grosse et al., 2013a; Morgenstern et al., 2013; Lenz et al., 2013; Kanevskiy et al., 2014; Jones and Arp, 2015). Thermokarst lake formation and growth is generally associated with periods of warming and wetting in the Arctic, and was especially intense during the Lateglacial and Early Holocene (Kaplina and Lozhkin, 1979; Walter et al., 2007). However, the development of specific thermokarst lakes and drained thermokarst lake basins is often triggered by local disturbances (Burn and Smith, 1990; Jorgenson et al., 2006). Because of the widespread occurrence of thermokarst lakes during periods of rapid Arctic change, they have a cumulative impact on the carbon and water cycles, climate feedbacks and energy balance of the northern high latitudes (Grosse et al., 2013a). For instance, thawing permafrost releases organic matter for microbial decomposition and in water-saturated, anaerobic conditions below thermokarst lakes methane is produced and emitted to the atmosphere (Walter et al., 2006). However, during their life cycle, thermokarst lakes act as long-term net carbon sinks accumulating organic-rich deposits before and after lake drainage (Walter Anthony et al., 2014).

To understand current and future developments of thermokarst lake dynamics and their feedbacks with landscapes, ecosystems and biogeochemical cycles, it is critical to investigate records of past thermokarst lake processes, driving factors and environmental conditions.

Using lake sediments to reveal past landscape dynamics is of great value because they comprise both minerogenic and organogenic compounds deposited during a specific environment within the lake's lifetime. Few studies have focused on core-based palaeoenvironmental reconstructions from thermokarst lakes to reveal permafrost and landscape dynamics (e.g. northwest Canada: Lenz et al., 2013; Siberia: Biskaborn et al., 2013a, 2013b; Schleusner et al., 2015; north Alaska: Gaglioti et al., 2014). In western Alaska, studied lake archives are often of non-thermokarst origin, for example, Imuruk Lake in the centre of the Seward Peninsula (Hopkins, 1959, 1963; Colinvaux, 1964), or undetermined origin as Kaiyak and Squirrel lakes south of the Brooks Range (Anderson, 1985; Berger and Anderson, 1994) and concentrate mostly on vegetative and climate change. Besides lake sediment cores, natural exposures along lakes, rivers and coasts have been used to study thermokarst lake deposits (e.g. Hopkins and Kidd, 1988; Wetterich et al., 2012). Fossil remains recovered from these records such as ostracods, molluscs and testate amoebae (rhizopods) enable the characterisation of past ecological conditions during thermokarst lake formation and growth. For example, Wetterich et al. (2012) used these bioindicators as well as pollen and plant macrofossils from a pingo exposure eroded by coastal erosion of the Chukchi Sea to infer a regional signal of late Quaternary landscape dynamics of the northern
Seward Peninsula. Palaeoenvironmental questions on the northern Seward Peninsula in northwest Alaska were addressed by studies on coastal bluffs along the Chukchi Sea (McCulloch and Hopkins, 1966; Matthews, 1974; Jordan and Mason, 1999; Wetterich et al., 2012), peatlands (Hunt et al., 2013) and the Kitluk palaeosol buried under the 18.0 ka BP Devil Mountain Maar tephra (Höfle and Ping, 1996; Höfle et al., 2000; Goetcheus and Birks, 2001; Kuzmina et al., 2008).

Regional thermokarst dynamics on a modern, decadal timescale with calculated expansion and drainage rates are presented by Jones et al. (2011). However, records of long-term permafrost processes and thermokarst activity from drained lake basins are rare on the northern Seward Peninsula. This region is of particular interest due to its location close to the modern treeline and within the continuous permafrost region but with relatively warm ground temperatures of -5 to $-2{ }^{\circ} \mathrm{C}$ (Romanovsky et al., 2010; Smith et al., 2010).

We studied a sediment core obtained from a recently drained thermokarst lake basin on a yedoma upland located on the northern Seward Peninsula (Figures 1 and 2). Here we present a multiproxy record from this basin and discuss the development of a thermokarst lake system on the northern Seward Peninsula in ice-rich yedoma of central Beringia throughout the late Pleistocene and Holocene.

\section{STUDY AREA}

The study region is part of the Bering Land Bridge National Preserve and is located in the central region of Beringia,

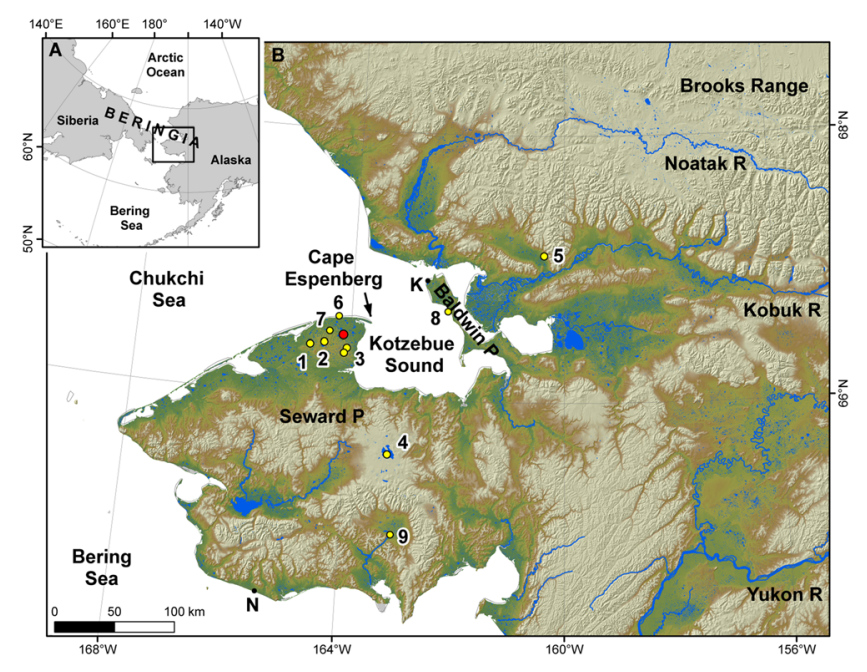

Figure 1 Study area of the northern Seward Peninsula as part of the Bering Land Bridge National Preserve (A and B). Red dot $=$ Kit-64 study site; $\mathrm{K}=$ Kotzebue; $\mathrm{N}=$ Nome; 1 = Whitefish Maar; 2 = Devil Mountain Maar; $3=$ North and South Killeak maars; 4 = Imuruk Lake (Hopkins, 1959, 1963; Colinvaux, 1964); 5 = Squirrel Lake (Anderson, 1985; Berger and Anderson, 1994); 6 = Kit-1 Pingo (Wetterich et al., 2012); 7 = Tempest Lake (Kuzmina et al., 2008); 8 = mammoth site (Hopkins et al., 1976); $9=$ Niukluk Lake (Hunt et al., 2013). This figure is available in colour online at wileyonlinelibrary.com/journal/ppp 


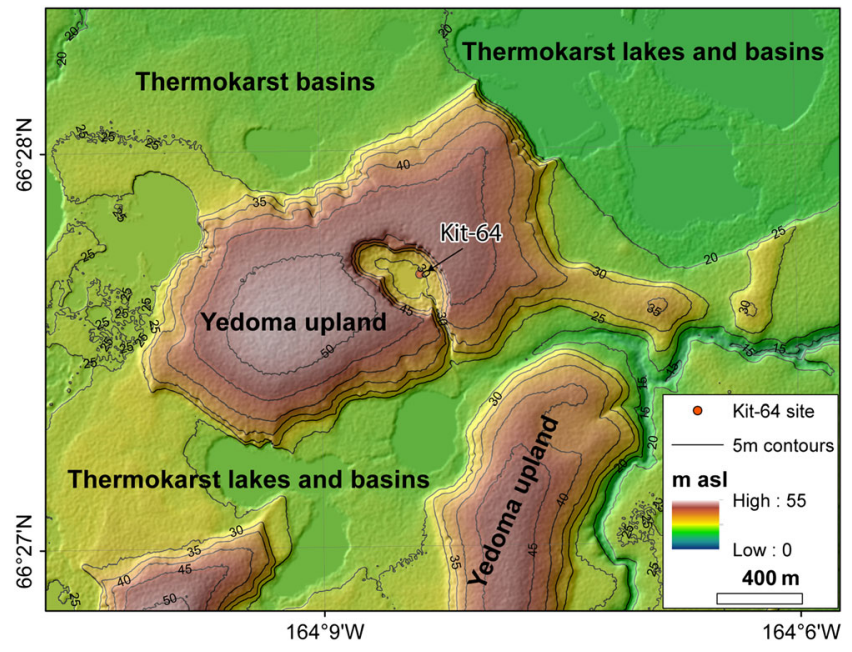

Figure 2 Digital elevation model of the drained basin with Kit-64 coring location in a yedoma upland surrounded by thermokarst lakes and basins. This figure is available in colour online at wileyonlinelibrary.com/journal/ ppp

which remained largely unglaciated during the Last Glacial Maximum (LGM, 26.5-19ka BP) (Hopkins, 1967; Kaufman and Hopkins, 1986). The gently northwardsloping plain with elevations mostly below $60 \mathrm{~m}$ asl is underlain by ice-rich, continuous permafrost (Brown et al., 2001). On the northern Seward Peninsula, permafrost is approximately $100 \mathrm{~m}$ thick (Jorgenson et al., 2008). Because of the lower glacial sea level during the LGM and the extensively exposed Bering and Chukchi Sea continental shelves, our study site was located in a central part of the wide Bering Land Bridge and dominated by a continental climate (Hopkins, 1967).

The northern Seward Peninsula represents one of the major lake districts in Alaska with extant lakes $>1$ ha covering $456 \mathrm{~km}^{2}(7.1 \%)$ (Arp and Jones, 2009). Up to $75 \%$ of the landscape is studded with drained thermokarst lake basins demonstrating a dynamic landscape history (Hopkins and Kidd, 1988; Jones et al., 2012). The local geomorphology is dominated by thermokarst lakes, drained thermokarst lake basins, remnants of yedoma uplands with ice-rich permafrost, erosional gullies, small streams, pingos and polygonal patterned ground (Jones et al., 2011; Regmi et al., 2012), hence our study site represents a typical landscape feature in this region. While the yedoma uplands are remnants of the late Pleistocene accumulation surface, most other features are of Holocene age and related to permafrost degradation and re-aggradation processes.

Late Quaternary volcanic landforms are also present in the region including the four large Espenberg Maar lakes, Devil Mountain Volcano and several smaller Quaternary volcanic cone remnants south of the study area (Hopkins, 1988; Begét et al., 1996). The Devil Mountain Maar was created by multiple phreatomagmatic eruptions at $17.5 \mathrm{ka}$ BP (Hopkins, 1988; Begét et al., 1996) and covers an area of $30 \mathrm{~km}^{2}$. Its tephra is distributed mostly towards the north and west over an area of about $2500 \mathrm{~km}^{2}$ (Begét et al., 1996; Höfle et al., 2000). The two maar craters of the North and South Killeak lakes are 12 and $20 \mathrm{~km}^{2}$ in area, respectively. South Killeak Maar was formed by about $42 \mathrm{ka} \mathrm{BP}$ while North Killeak Maar is most likely older than $125 \mathrm{ka}$ (Hopkins, 1988). The shallow Whitefish Maar located further west is estimated to be $100-200 \mathrm{ka}$ old, and five small shield volcanoes immediately south appear to be even older than the maars and may have formed prior to permafrost formation on the northern Seward Peninsula (Hopkins, 1988).

The study area today is characterised by a subarctic climate with mean annual air temperatures of $-6^{\circ} \mathrm{C}$ in Kotzebue about $60 \mathrm{~km}$ northeast of the study site. The January mean air temperature is $-20^{\circ} \mathrm{C}$ while the July mean air temperature is $12^{\circ} \mathrm{C}$. Precipitation averages $230 \mathrm{~mm} \mathrm{a}^{-1}$ with more than half the precipitation falling as rain in summer and early fall (US National Weather Service data, http://www.ncdc.noaa.gov/). The modern vegetation is classified as Bering Tundra (Nowacki et al., 2002). Elevated and better-drained sites are dominated by tussock sedge (Eriophorum vaginatum) and dwarf shrubs (Ledum palustre, Vaccinium vitis-idaea), whereas drier habitats like pingos are occupied by erect shrubs (Andromeda polifolia, Betula nana, Spiraea beauverdiana). Waterlogged acidic sites are characterised by Drepanocladus spp. and Sphagnum spp. as well as wet sedge-moss communities (Carex aquatilis, $E$. augustifolium) (Wetterich et al., 2012).

The shape of the 11.9 ha large study basin suggests that two originally separate lakes coalesced to form the present lake basin (Figures 2 and 3; Table 1). The main basin with a SW-NE extension of $270 \mathrm{~m}$ and a NW-SE extension of $330 \mathrm{~m}$ is connected at its NW edge over a length of $140 \mathrm{~m}$ to a small, round basin of a diameter of $170 \mathrm{~m}$. The lake had no inflow but based on field observations of other similar lake basins in the study area (Jones et al., 2011; Jones et al., 2012), we assume that this lake had a seasonal outflow channel which ultimately became the drainage gully. Remote sensing images suggest that the lake drained catastrophically in 2005. The drainage channel is located south of the basin and leads $275 \mathrm{~m}$ through the upland down to the lowland drainage system. The slopes of the basin incline $28^{\circ}$ at their maximum $\left(9^{\circ}\right.$ mean) and are about $20 \mathrm{~m}$ high. Prior to drainage, the lake had an average depth of $12 \mathrm{~m}$. Neither soil developed nor vegetation recovered after the lake drainage. Remnant pools of water are still present in the centre of the basin and covered an area of 0.96 ha in the main basin and 0.07 ha in the adjacent basin in September 2011. The main basin floor is elevated about 29 to $31 \mathrm{~m}$ asl and moderately flat but pronounced baydzherakhs of about $10 \mathrm{~m}$ in diameter and up to $1 \mathrm{~m}$ height are present. Baydzherakhs are conical mounds consisting of ice-wedge polygon centres that are separated by deep troughs from melting of large ice wedges (Soloviev, 1962, cited in French, 1974). Our sediment core was taken from the top of a baydzherakh at $66^{\circ} 27^{\prime} 41^{\prime \prime} \mathrm{N}$ and $164^{\circ} 8^{\prime} 22^{\prime \prime} \mathrm{W}$. 

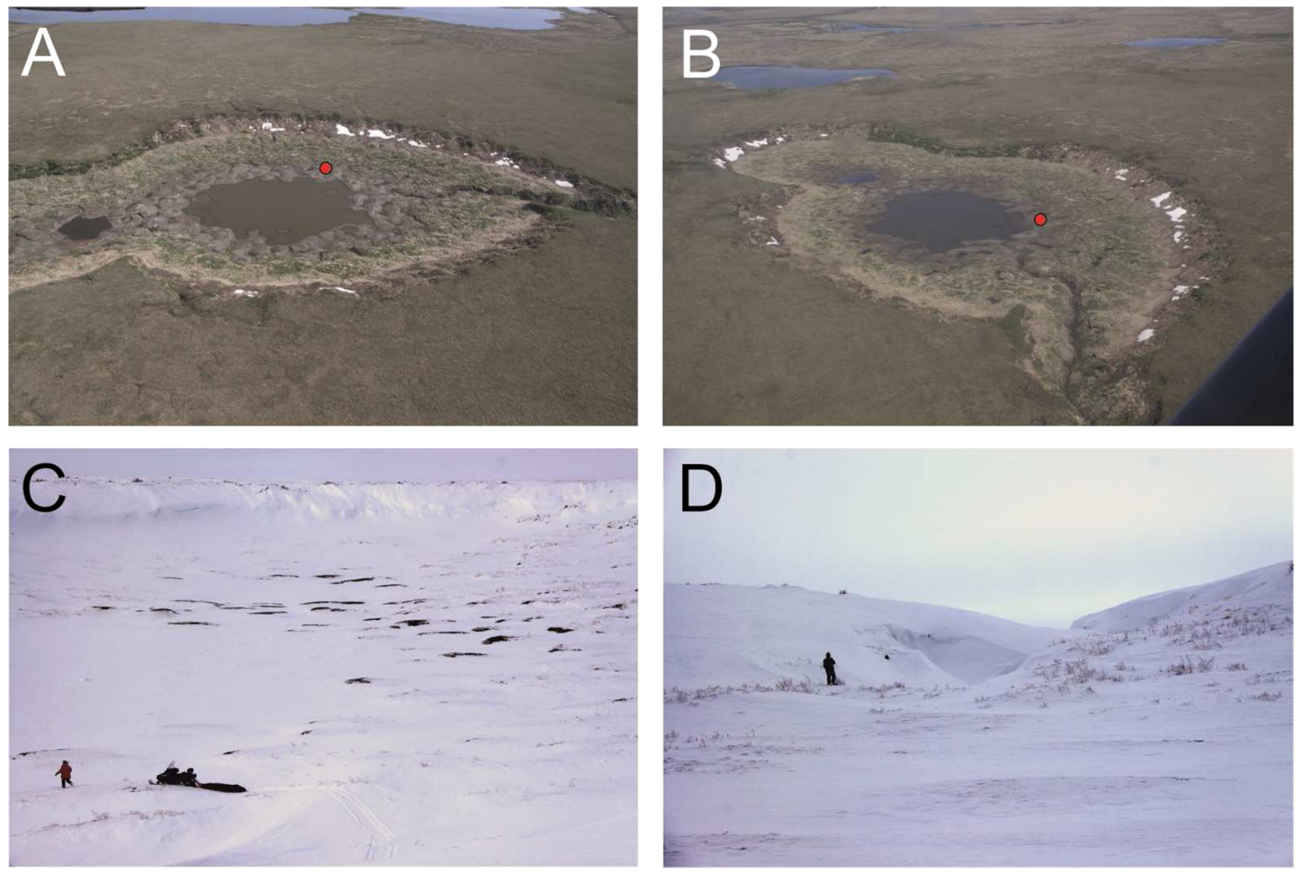

Figure 3 Aerial photographs of GG basin with coring location of Kit-64 (red dot). (A) View of the drained basin from southwest to northeast (June 2011); (B) view from south to north; (C) photograph of the southeastern basin margin (April 2009). Note the presence of exposed baydzherakh centres on the basin floor; (D) start of the outflow channel of the basin, which is covered with a large snow drift. Person for scale. See text for abbreviation. This figure is available in colour online at wileyonlinelibrary.com/journal/ppp

Table 1 Metric statistics of GG basin and GG lake derived from satellite images and the digital elevation model.

\begin{tabular}{lcc}
\hline & $\begin{array}{c}\text { GG lake } \\
\text { (AHAP 1980) }\end{array}$ & $\begin{array}{c}\text { GG basin } \\
\text { (Worldview 2011) }\end{array}$ \\
\hline Area & $7.9 \mathrm{ha}$ & $11.9 \mathrm{ha}$ \\
Elevation yedoma upland & $48 \mathrm{~m} \mathrm{asl}$ & $48 \mathrm{~m}$ asl \\
Elevation lake level & $40.5 \mathrm{~m}$ asl & n.a. \\
Elevation basin floor & n.a. & $28.5 \mathrm{~m}$ asl \\
Average bluff height & $7.5 \mathrm{~m}$ & $19.5 \mathrm{~m}$ \\
Approximate lake depth & $12.0 \mathrm{~m}$ & n.a. \\
Total basin depth & n.a. & $19.5 \mathrm{~m}$ \\
Volume & $712000 \mathrm{~m}^{3}$ & $1578000 \mathrm{~m}^{3}$ \\
Mean slope/Max slope & $5.8^{\circ} / 24.5^{\circ}$ & $9.0^{\circ} / 25.7^{\circ}$ \\
\hline
\end{tabular}

AHAP = Alaska High-Altitude Photography; n.a. = not applicable; asl = above sea level.

\section{MATERIAL AND METHODS}

To reveal the complex landscape history and interaction of land-forming periglacial processes, a multidisciplinary approach was chosen using sedimentological, biogeochemical and palaeoecological proxies on a sediment core.

As part of a larger permafrost and thermokarst-focused field campaign on the northern Seward Peninsula in April 2009, a $393 \mathrm{~cm}$ core (core ID: Kit-64) was drilled in the thermokarst lake basin described above (informal name: GG basin) (Figures 2 and 3). The upper frozen sediment section from $0-268 \mathrm{~cm}$ was drilled with a SIPRE permafrost corer (Jon Holmgren's Machine Shop, Fairbanks, Alaska, USA). For the unfrozen lower $268-393 \mathrm{~cm}$, a piston hammer corer (Aquatic Instruments, Hope, Montana, USA) was used (all depths are given as centimetres below surface). In the laboratory, both the frozen and unfrozen core segments, were cut into halves and high-resolution digital photographs were taken with an optical camera system. A non-destructive analysis of mass-specific magnetic susceptibility (MS) was conducted at the National Lacustrine Core Facility (LacCore) at the University of Minnesota with a Multi-Sensor Core Logger (GEOTEK-MSCL, Daventry, UK). The SI system is used to express MS values in $10^{-6}$. After scanning, core halves were stored frozen or refrigerated, depending on their original field state.

The sediment core was described in detail and subsampled for further analyses at the Alfred Wegener Institute, Helmholtz Centre for Polar and Marine Research in Potsdam, Germany. Porewater was extracted from the frozen core section with rhizon soil moisture samplers $(0.2 \mu \mathrm{m}$ pore diameter, Eijkelkamp, Giesbeek, Netherlands), and electrical conductivity (EC) in $\mu \mathrm{S} \mathrm{cm}^{-1}\left(\mathrm{~T}_{\text {Ref }} 25^{\circ} \mathrm{C}\right.$ ) and $\mathrm{pH}$ (both MultiLab 549, WTW, Weilheim, Germany) were measured in fresh water samples. The weight difference between fresh and freeze-dried bulk sediment samples was used to calculate the ice or water content, respectively, which is expressed as weight percentage (wt\%). After the removal of organic matter with hydrogen peroxide $\left(\mathrm{H}_{2} \mathrm{O}_{2}, 30 \%\right)$, grain size distribution was measured with a laser particle size analyser (Coulter LS 
200, Krefeld, Germany) according to EN ISO 14688. Particles $>1 \mathrm{~mm}$ were dry-sieved for $2 \mathrm{~min}$ through $2 \mathrm{~mm}$ mesh screens (ATM Sonic Sifter, West Allis, Wisconsin, USA) in order to differentiate gravel.

Total nitrogen (TN), total carbon (TC) and total organic carbon (TOC) were measured in bulk sediments with an elemental analyser (ElementarVario EL III, Hanau, Germany) with an analytical accuracy of $\pm 0.1 \mathrm{wt} \%$. The $\mathrm{C} / \mathrm{N}$ ratio (TOC/TN) was calculated. Values of $\delta^{13} \mathrm{C}$ of TOC were analysed with a Finnigan MAT Delta-S (Bremen, Germany) mass spectrometer equipped with a FLASH elemental analyser and a CONFLO III (Bremen, Germany) gas mixing system for the online determination of the carbon isotopic composition. Values of $\delta^{13} \mathrm{C}$ are expressed relative to the Vienna Pee Dee Belemnite (PDB) standard in per mil $(\% \circ)$ and the standard deviation $(1 \sigma)$ is generally better than $\delta^{13} \mathrm{C}= \pm 0.15 \%$.

Volcanic glass shards in tephra layers were identified on smear slides in glycerin and prepared for geochemical microanalyses in order to identify the source of tephras. Samples were treated with hydrogen peroxide $\left(\mathrm{H}_{2} \mathrm{O}_{2}\right.$, $15 \%)$ to remove organic matter, treated with hydrogen chloride $(\mathrm{HCl}, 10 \%)$ to remove carbonates, wet-sieved through 35 and $125 \mu \mathrm{m}$, rinsed in ethanol, dried and embedded in resin on a glass slide. After manual grinding and polishing of samples, the major element glass composition was analysed by a JEOL JXA-8230 (Munich, Germany) electron microprobe with a voltage of $15 \mathrm{kV}$, a beam current of $10 \mathrm{nA}$ and a beam size of $10 \mu \mathrm{m}$. Natural and synthetic minerals and Lipari obsidian were used for instrumental calibration and standardisation (Hunt and Hill, 1996; Kuehn et al., 2011). Scanning electron microscopy (SEM) images (Zeiss Gemini Ultra+, Jena, Germany) were taken at German Research Centre for Geosciences Potsdam (GFZ) to visualize ash particles.

Palaeoecological analyses were carried out to characterise past ecological conditions. Sediment samples with known weight were wet-sieved through 63 and $200 \mu \mathrm{mmesh}$ screens, dried and examined under a stereo-microscope (Zeiss Stemi 2000-C, Jena, Germany) for species determination of ostracods. Selected ostracod valves were coated with electrically conducting carbon for SEM images at 40x magnification at the GFZ. Testaceans were identified and counted in glycerin on a glass slide under a light microscope at 100x to 400x magnification (Zeiss Axioskop 2) after subsamples were suspended in purified water and passed through a $500 \mu \mathrm{m}$ mesh sieve to remove organic and mineral particles. Occasional findings of single diatom algae specimens and ash particles have been recorded.

Accelerator Mass Spectrometry (AMS) radiocarbon age determination of macroscopic plant remains was carried out on wet-sieved $(>250 \mu \mathrm{m})$ and hand-picked samples. Thirteen samples of plant detritus were dated at the Poznan Radiocarbon Laboratory (Poland) and results were calibrated using CALIB 7.0 with the INTCAL13 data-set (Reimer et al., 2013). The calibration of seven samples was impossible due to old radiocarbon ages extending beyond the calibration data-set. Dates in this study are reported in uncalibrated years before AD 1950, referred to as before present (ka BP), for reasons of unification. Calibrated radiocarbon ages (cal ka BP) are given in Table 2.

\section{RESULTS}

\section{Core Stratigraphy}

The sediment core Kit-64 is characterised by grey, finegrained deposits with organic inclusions and layers (Figure 4). Based on lithological descriptions and the analysed sedimentary, biogeochemical and palaeoecological parameters, the sediment core is divided into five lithostratigraphic units:

$$
\begin{aligned}
& \text { - Unit A: } 393-262 \mathrm{~cm} \\
& \text { - Unit B: } 262-245 \mathrm{~cm} \\
& \text { - Unit C: } 245-146 \mathrm{~cm} \\
& \text { - Unit D: } 146-36 \mathrm{~cm} \\
& \text { - Unit E: } 36-0 \mathrm{~cm}
\end{aligned}
$$

Unit A (393-262 cm) comprised the unfrozen sediment section and a small portion of $4 \mathrm{~cm}$ of the frozen segment. It was characterised by a dark greyish brown to very dark brown colour (Munsell Soil Color Chart (1994), ID 10YR $4 / 2$ to $2 / 2$ ), unlayered but marbled silt with thick lenses of black (10YR 2/1), well-decomposed organic matter with single pieces of woody remains up to $1 \mathrm{~cm}$ long at $386.5 \mathrm{~cm}$ and $306 \mathrm{~cm}$. Between 310 and $288 \mathrm{~cm}$, the sediment was interpreted as disturbed since the borehole filled back in at these depths during the drilling process. Unit B $(262-245 \mathrm{~cm})$ was a dark olive brown peat $(2.5 \mathrm{Y} 3 / 2)$ which was well decomposed at $262-250 \mathrm{~cm}$ and poorly decomposed with woody remains of up to $2 \mathrm{~cm}$ length at $264-262 \mathrm{~cm}$. Unit C (245-146 cm) was composed of very dark grey (5Y $3 / 1)$ to black (2.5Y 2.5/1) minerogenic sediments that were mainly made up of coarse-grained tephra material (grain size up to $7 \mathrm{~mm}$ at $182 \mathrm{~cm})$. Unit D $(146-36 \mathrm{~cm})$ was olive $(5 \mathrm{Y}$ $4 / 4$ ) to dark olive grey (5Y 3/2) in colour and characterised by fine-grained sediments with organic-rich inclusions including woody remains at $146-143 \mathrm{~cm}, 141-137 \mathrm{~cm}$, $117-112 \mathrm{~cm}$ and $111-109 \mathrm{~cm}$. From $120 \mathrm{~cm}$, upward slight layering was visible and became more distinct above $64 \mathrm{~cm}$. Unit E $(36-0 \mathrm{~cm})$ compromised fine-grained, olive (5Y 4/4) sediments. Here, distinct laminations were visible by colour with thicker laminae of about $1 \mathrm{~mm}$ at $3-0 \mathrm{~cm}$ and thinner laminae of $<0.5 \mathrm{~mm}$ at $64-3 \mathrm{~cm}$. Macrofossil plant remains were observed throughout unit $\mathrm{E}$, and mollusc shells were identified at $25 \mathrm{~cm}$ (both valves of $3 \mathrm{~mm}$ length), $22 \mathrm{~cm}$ and $11 \mathrm{~cm}$.

\section{Cryostratigraphy}

The upper part from $266-0 \mathrm{~cm}$ (small part of unit A as well as unit B to unit E) was recovered frozen while the lower 
Table 2 AMS ${ }^{14} \mathrm{C}$ ages from core Kit-64.

\begin{tabular}{|c|c|c|c|c|c|c|c|}
\hline $\begin{array}{l}\text { Core depth } \\
(\mathrm{cm})\end{array}$ & Dated plant material & $\begin{array}{l}\text { Mass } \\
(\mathrm{mgC})\end{array}$ & $\begin{array}{c}\delta^{13} \mathrm{C} \\
(\% o)\end{array}$ & $\begin{array}{l}\text { Uncalibrated } \\
{ }^{14} \mathrm{C} \text { age } \\
\quad(\mathrm{a} \mathrm{BP})\end{array}$ & $\begin{array}{l}\text { Calibrated } 2 \sigma \text {-range } \\
\text { (cal a before } \\
\text { christ }(\mathrm{BC}))\end{array}$ & $\begin{array}{l}\text { Mean } 2 \sigma \text {-age } \\
\quad(\text { cal a BP })\end{array}$ & Lab. no. \\
\hline $2-3$ & $\begin{array}{l}\text { Rootlets, leaves and shoots, } \\
<1 \% \text { moss }\end{array}$ & 1.5 & -29 & $6270 \pm 40$ & $5324-5205$ & $7200 \pm 60$ & Poz-49845 \\
\hline $27-28$ & Rootlets of higher plants & 0.7 & -30 & $230 \pm 30$ & $314-286$ & $290 \pm 23$ & Poz-61951 \\
\hline $36-37$ & $\begin{array}{l}\text { Rootlets of higher plants, } \\
\text { lignified shoots and leaves }\end{array}$ & 2.3 & -27 & $22530 \pm 160$ & 25 319-24 454 & $26800 \pm 430$ & Poz-49846 \\
\hline $47.5-48.5$ & Woody fragments & 1.2 & -30.7 & $23890 \pm 130$ & $26313-25733$ & $28000 \pm 290$ & Poz-61952 \\
\hline 114 & $\begin{array}{l}\text { Rootlets of higher plants, } \\
\text { lignified shoots and leaves }\end{array}$ & 1.3 & -27 & $33300 \pm 500$ & $36725-34323$ & $37500 \pm 1200$ & Poz-49847 \\
\hline $140-141$ & Woody fragments & 3.1 & -32.1 & $36500 \pm 500$ & 39 996-38 131 & $39100 \pm 930$ & Poz-61953 \\
\hline $186-187$ & Lignified shoots and leaves & 0.1 & -34.3 & $31100 \pm 500$ & $34078-32171$ & $35100 \pm 950$ & Poz-49848 \\
\hline $196-197$ & Lignified shoots and leaves & 0.4 & -34.2 & $46500 \pm 3500$ & a & a & Poz-49849 \\
\hline $250-251$ & Mostly Carex rootlets and leaves & 2.02 & -28.1 & $41500 \pm 1500$ & $45889-40562$ & $45200 \pm 2700$ & Poz-49851 \\
\hline $263-264$ & $\begin{array}{l}\text { Rootlets and leaves, lignified } \\
\text { shoots and branches }\end{array}$ & 1.35 & -26.3 & $44500 \pm 2000$ & {$\left[\begin{array}{lll}48 & 051\end{array}\right]-42682$} & & Poz-49852 \\
\hline 278 & $\begin{array}{l}\text { Lignified shoots and branches, } \\
\text { leaves and rootlets }\end{array}$ & 2.27 & -28.3 & $43500 \pm 2000$ & {$\left[\begin{array}{ll}48 & 051\end{array}\right]-41885$} & a & Poz-49853 \\
\hline 287 & $\begin{array}{l}\text { Lignified shoots and branches, } \\
\text { leaves and rootlets }\end{array}$ & 2.31 & -20.3 & $41500 \pm 1000$ & $44713-41177$ & $44900 \pm 1800$ & Poz-50096 \\
\hline 306 & $\begin{array}{l}\text { Lignified shoots and branches, } \\
\text { leaves and rootlets }\end{array}$ & 2.19 & -26.5 & $45000 \pm 2000$ & {$\left[\begin{array}{ll}48 & 051\end{array}\right]-43055$} & a & Poz-49855 \\
\hline 352 & $\begin{array}{l}\text { Lignified shoots and branches, } \\
\text { rootlets, leaves }\end{array}$ & 1.73 & -24.2 & $>44000$ & a & a & Poz-49856 \\
\hline 372 & $\begin{array}{l}\text { Lignified shoots and branches, } \\
\text { rootlets }\end{array}$ & 2.83 & -27.6 & $>48000$ & $\mathrm{a}$ & $\mathrm{a}$ & Poz-49857 \\
\hline 391 & $\begin{array}{l}\text { Lignified shoots and branches, } \\
\text { non-lignified plant remains }\end{array}$ & 2.31 & -20.3 & $>49000$ & a & a & Poz-49866 \\
\hline
\end{tabular}

Calibrated ${ }^{14} \mathrm{C}$ ages were derived using CALIB 7.0 based on the terrestrial radiocarbon age calibration INTCAL13 (Reimer et al., 2013). ${ }^{\text {a }}$ Calibration was not possible due to old ${ }^{14} \mathrm{C}$ ages. Poz $=$ Poznan Radiocarbon Laboratory.

part from 393-266 cm (most part of unit A) was unfrozen. The mean gravimetric water content of unfrozen unit A was $26.8 \mathrm{wt} \%$ (max: $51.1 \mathrm{wt} \%$, min: $14.3 \mathrm{wt} \%$ ) and a single sample from the uppermost, frozen portion of unit A yielded an ice content of $19 \mathrm{wt} \%$.

For our cryostructure description, we followed the classification scheme according to Murton and French (1994). The frozen upper $4 \mathrm{~cm}$ of unit A were ice-poor and structureless. Units B and C were also structureless with no visible ice lenses. However, mean ice contents were $55.8 \mathrm{wt} \%$ in unit B and $22.5 \mathrm{wt} \%$ in unit C. The lower section of unit D was structureless, but wavy, non-parallel lenticular ice lenses were visible at $152-150 \mathrm{~cm}$ and wavy, parallel micro-lenticular ice lenses showed at $93-83 \mathrm{~cm}$. Sub-vertical ice veins of up to $5 \mathrm{~cm}$ and $9 \mathrm{~cm}$ lengths were identified at $124-115 \mathrm{~cm}$ and $83-74 \mathrm{~cm}$, respectively. In the upper section of unit D, small irregular ice veins were observed at $65-63 \mathrm{~cm}$. Wavy, parallel lenticular cryostructures dominated at $60-44 \mathrm{~cm}$ with thin vertical ice veins of up to $11 \mathrm{~cm}$ long. Cryostructures at $44-36 \mathrm{~cm}$ were structureless again. Mean ice content in unit D was $32.7 \mathrm{wt} \%$ with a wide range between 22.3 and $46.7 \mathrm{wt} \%$. The cryostructure of unit E was parallel micro-lenticular at $36-24 \mathrm{~cm}$ and irregular reticulate at $25-6 \mathrm{~cm}$. Parallel lenticular structures with ice lenses of $4 \mathrm{~cm}$ length and $2 \mathrm{~mm}$ thickness dominated at $6-3 \mathrm{~cm}$, whereas the uppermost $3 \mathrm{~cm}$ below the surface were structureless, possibly due to sublimation processes at the exposed drained basin surface during winter. Mean ice content was similar to unit D with $37.5 \mathrm{wt} \%$ and ranged from $44.4 \mathrm{wt} \%$ at $11-10 \mathrm{~cm}$ to $29.9 \mathrm{wt} \%$ near the surface at $2-1 \mathrm{~cm}$.

\section{Grain Size Distribution}

The granulometric results integrated the laminations and general trends in sedimentological variations. According to the nomenclature used by Shephard (1954), the sediment core was dominated by silt with varying proportions of clay and sand (Figure 5). A notable exception was the grain size distribution in unit $\mathrm{C}$ and the lower part of unit D. Here, sand and silty sand were dominating with fractions of gravel mainly in samples at a depth of 181-130 cm (Figures 5 and S1).

In units $\mathrm{E}, \mathrm{D}, \mathrm{B}$ and $\mathrm{A}$, mean grain sizes ranged from 5.9 to $6.2 \Phi$ (silt) after Folk and Ward (1957). Unit $C$ is characterised by $2.5 \Phi$ (sand). The sediment of the whole core was poorly to very poorly sorted (2.0 to 2.4 on average after Folk and Ward, 1957). 


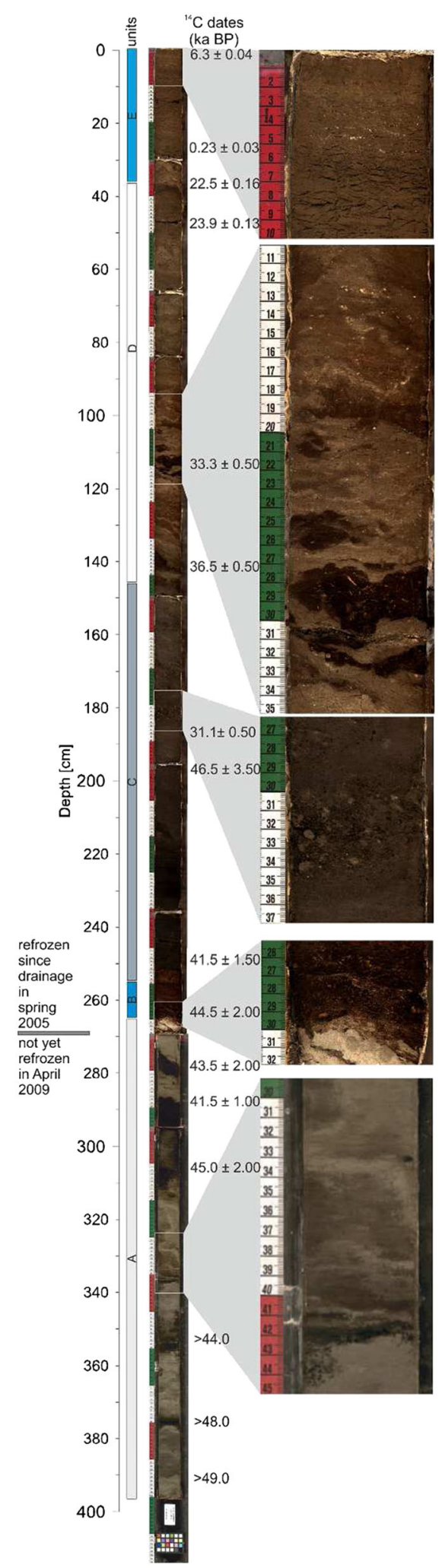

Figure 4 Photograph of core Kit-64 and detailed images of each unit. Note the unfrozen state of sediment below $268 \mathrm{~cm}$. Radiocarbon ages are given in uncalibrated years before present. This figure is available in colour online at wileyonlinelibrary.com/journal/ppp

\section{Magnetic Susceptibility}

The MS in the core data varied between 0 and 206 (Figure 5). In unit A, MS generally decreased up-core from about 66 to 0 but distinct higher values up to 144 were measured between 298 and $293 \mathrm{~cm}$. In unit B, MS values increased to 90 . The tephra-dominated unit $\mathrm{C}$ exhibited the highest variability of all core units and the highest values of MS of 200 to 206 at about $186-177 \mathrm{~cm}$ (average MS of 139). Unit D was less variable (33 on average) with the highest MS value of 78 at the boundary to unit C and the lowest MS of 15 at $82 \mathrm{~cm}$. Unit $\mathrm{E}$ was similar to unit D with an MS value of 33 on average and a minimum of 23 and maximum of 40 .

\section{Biogeochemical Characteristics}

In unit $\mathrm{A}$, the $\mathrm{TN}, \mathrm{TC}$ and TOC were $0.6,8.5$ and $7.6 \mathrm{wt} \%$ on average, respectively. A distinct increase in organic carbon content was noted at $305-277 \mathrm{~cm}$. Here, $\mathrm{TN}_{\text {Max }}$ was $2.3 \mathrm{wt} \%, \mathrm{TC}_{\mathrm{Max}}$ was $36.6 \mathrm{wt} \%$ and $\mathrm{TOC}_{\text {Max }}$ was $34.5 \mathrm{wt} \%$ (Figure 5 ). The $\mathrm{C} / \mathrm{N}$ ratio was relatively steady with 11.3 on average. The $\delta^{13} \mathrm{C}$ values in unit $\mathrm{A}$ ranged from $-27.5 \%$ to $-25.2 \%$ with a clear negative trend towards the top of the core. In unit B, TN was $1.9 \mathrm{wt} \%$. TOC and TC were nearly the same ( $32 \mathrm{wt} \%$ and $31.5 \mathrm{wt} \%$, respectively) due to the peaty character of this unit. The $\mathrm{C} / \mathrm{N}$ ratio in unit $\mathrm{B}$ was 17.1 and $\delta^{13} \mathrm{C}$ was $-28.1 \%$ on average. TN was mostly below the detection limit of $0.1 \mathrm{wt} \%$ in unit C. TC and TOC were also low with $0.4 \mathrm{wt} \%$ and $0.3 \mathrm{wt} \%$ on average, respectively. This resulted in an average $\mathrm{C} / \mathrm{N}$ ratio of 2.7. Values of $\delta^{13} \mathrm{C}$ were relatively stable at about $-25.0 \%$ o. The biogeochemical properties in unit $\mathrm{C}$ clearly reflected dominance of tephra material in this sediment. In unit $\mathrm{D}$, biogeochemical parameters varied especially near the transition to unit $\mathrm{C}$ at $146 \mathrm{~cm}$ and $100 \mathrm{~cm}$ (Figure 5). Average TN, TC and TOC were 0.6, 6.9 and $6.2 \mathrm{wt} \%$, respectively. The $\mathrm{C} / \mathrm{N}$ ratio was 9.9 . Values of $\delta^{13} \mathrm{C}$ ranged between $-28.1 \%$ and $-26.4 \%$. Unit $\mathrm{E}$ exhibited the highest values of TN, TC and TOC at the base of the deposits that decreased upwards until they reached plateau values of 0.4 , 4.6 and $4.0 \mathrm{wt} \%$, respectively, in the upper $21 \mathrm{~cm}$. The C/N ratio was 11.3 and $\delta^{13} \mathrm{C}$ ranged between $-27.8 \%$ and $-26.6 \%$ o in unit $\mathrm{E}$.

\section{Tephra}

Unit $\mathrm{C}$ consisted of a $1 \mathrm{~m}$ thick layer of volcanic air-fall tephra. The geochemical composition of this tephra was analysed in order to identify the eruptive source and the potential to add tephra geochronological information (Tables 3 and S1). As displayed in Table 3, all samples between 243 and $155 \mathrm{~cm}$ yielded a similar basaltic-trachybasaltic to basaltic andesitic glass composition pointing to a single eruption source for the entire layer. However, differences in particle size indicated different eruption phases of unknown duration. Sharp edges and pronounced vesicles of glass shards indicated a low stage of alteration which in turn 


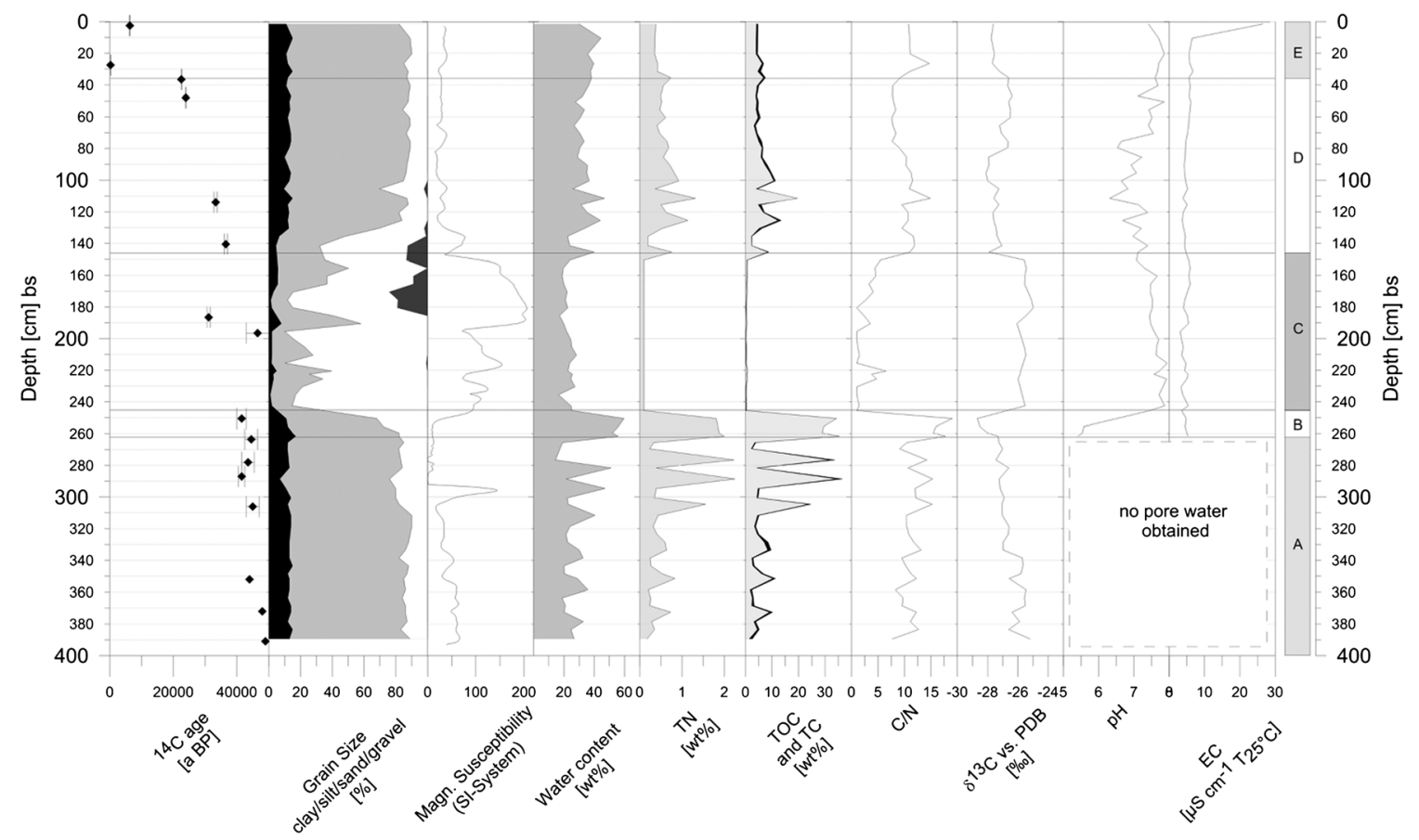

Figure 5 Geochronological, lithological and sediment biogeochemical results for core Kit-64: AMS radiocarbon dates, grain size, magnetic susceptibility, water content, total nitrogen (TN), total carbon (TC) and total organic carbon (TOC), $\mathrm{C} / \mathrm{N}$ ratio, $\delta^{13} \mathrm{C}, \mathrm{pH}$ and electrical conductivity (EC) (only obtained from the frozen core sections). $\mathrm{Cm}$ bs $=$ Centimetres below surface. Pee Dee Belemnite (PDB).

Table 3 Electron probe microanalyses on glass shards of eight subsamples of tephra in unit C of the Kit-64 core from the Seward Peninsula.

\begin{tabular}{|c|c|c|c|c|c|c|c|c|c|c|c|c|c|}
\hline Sample & $\mathrm{SiO}_{2}$ & $\mathrm{TiO}_{2}$ & $\mathrm{Al}_{2} \mathrm{O}_{3}$ & $\mathrm{FeO}$ & $\mathrm{MnO}$ & $\mathrm{MgO}$ & $\mathrm{CaO}$ & $\mathrm{Na}_{2} \mathrm{O}$ & $\mathrm{K}_{2} \mathrm{O}$ & $\mathrm{P}_{2} \mathrm{O}_{5}$ & Total & $\mathrm{Cl}$ & $\mathrm{F}$ \\
\hline Kit-64, 155-156 cm & 51.35 & 2.76 & 14.96 & 9.95 & 0.15 & 5.50 & 9.53 & 3.91 & 1.39 & 0.50 & 100.00 & 0.04 & 0.00 \\
\hline $\mathrm{SD}(\mathrm{n}=24)$ & 0.76 & 0.18 & 0.42 & 0.40 & 0.03 & 0.33 & 0.34 & 0.15 & 0.21 & 0.04 & & 0.01 & 0.01 \\
\hline Kit-64, $160-166 \mathrm{~cm}$ & 51.06 & 2.44 & 15.55 & 9.70 & 0.15 & 6.03 & 9.44 & 3.88 & 1.28 & 0.47 & 100.00 & 0.03 & 0.00 \\
\hline $\mathrm{SD}(\mathrm{n}=23)$ & 0.54 & 0.14 & 0.30 & 0.34 & 0.03 & 0.28 & 0.18 & 0.21 & 0.06 & 0.03 & & 0.01 & 0.00 \\
\hline Kit-64, $175-181 \mathrm{~cm}$ & 51.61 & 2.59 & 15.24 & 9.72 & 0.14 & 5.65 & 9.30 & 3.85 & 1.41 & 0.49 & 100.00 & 0.03 & 0.00 \\
\hline $\operatorname{SD}(n=22)$ & 1.39 & 0.25 & 0.44 & 0.37 & 0.02 & 0.77 & 0.46 & 0.54 & 0.24 & 0.06 & & 0.01 & 0.00 \\
\hline Kit-64, 185-191 cm & 51.21 & 2.51 & 15.38 & 9.98 & 0.15 & 5.81 & 9.25 & 3.83 & 1.39 & 0.49 & 100.00 & 0.04 & 0.00 \\
\hline $\mathrm{SD}(\mathrm{n}=21)$ & 1.06 & 0.24 & 0.64 & 0.64 & 0.03 & 0.70 & 0.42 & 0.18 & 0.19 & 0.06 & & 0.01 & 0.01 \\
\hline Kit-64, 195-216 cm & 51.76 & 2.55 & 15.15 & 9.88 & 0.16 & 5.76 & 9.19 & 3.75 & 1.33 & 0.47 & 100.00 & 0.04 & 0.00 \\
\hline $\mathrm{SD}(\mathrm{n}=21)$ & 1.16 & 0.19 & 0.59 & 0.36 & 0.03 & 0.51 & 0.45 & 0.21 & 0.15 & 0.04 & & 0.01 & 0.00 \\
\hline Kit-64, 220-226 cm & 49.50 & 2.77 & 15.85 & 9.98 & 0.15 & 5.62 & 9.86 & 4.15 & 1.54 & 0.59 & 100.00 & 0.04 & 0.00 \\
\hline $\mathrm{SD}(\mathrm{n}=23)$ & 0.23 & 0.05 & 0.14 & 0.26 & 0.03 & 0.07 & 0.06 & 0.10 & 0.05 & 0.03 & & 0.01 & 0.02 \\
\hline Kit-64, 230-231 cm & 51.05 & 2.83 & 15.27 & 9.92 & 0.15 & 5.38 & 9.41 & 3.94 & 1.49 & 0.56 & 100.00 & 0.04 & 0.00 \\
\hline $\mathrm{SD}(\mathrm{n}=24)$ & 1.89 & 0.13 & 0.71 & 0.40 & 0.02 & 0.28 & 0.51 & 0.37 & 0.15 & 0.08 & & 0.01 & 0.00 \\
\hline Kit-64, 242-243 cm & 51.91 & 2.80 & 14.97 & 9.80 & 0.16 & 5.30 & 9.18 & 3.92 & 1.43 & 0.52 & 100.00 & 0.05 & 0.00 \\
\hline $\mathrm{SD}(\mathrm{n}=22)$ & 1.91 & 0.17 & 0.70 & 0.40 & 0.03 & 0.33 & 0.52 & 0.33 & 0.27 & 0.08 & & 0.01 & 0.01 \\
\hline
\end{tabular}

Data are expressed as normalised mean (volatile-free) values (wt\%) and their standard deviations (SD). Single non-normalised data of all samples and the Lipari obsidian reference standard are given in Supporting Information Table S1. $\mathrm{n}=$ Number of single glass shards analysed.

pointed to no or only very limited redeposition processes (Figure 6). Radiocarbon dating of lignified shoots and roots in the tephra deposit suggested an age of this layer between $46.5 \pm 3.5 \mathrm{ka} \mathrm{BP}$ and $31.1 \pm 0.5 \mathrm{ka}$ BP. This age range can be further specified by the directly under- and overlying sediments of units B and D that were dated to $41.5 \pm 1.5 \mathrm{ka} \mathrm{BP}$ and $36.5 \pm 0.5 \mathrm{ka} \mathrm{BP}$, respectively (see Geochronology).

\section{Palaeoecology}

Lacustrine Environments (porewater and ostracoda).

To characterise past lake conditions, porewater was extracted. No water was obtained from the unfrozen unit A. An acidic $\mathrm{pH}$ of about 5.5 was measured in unit B, whereas $\mathrm{pH}$ was neutral to moderately alkaline in unit $\mathrm{C}$ 

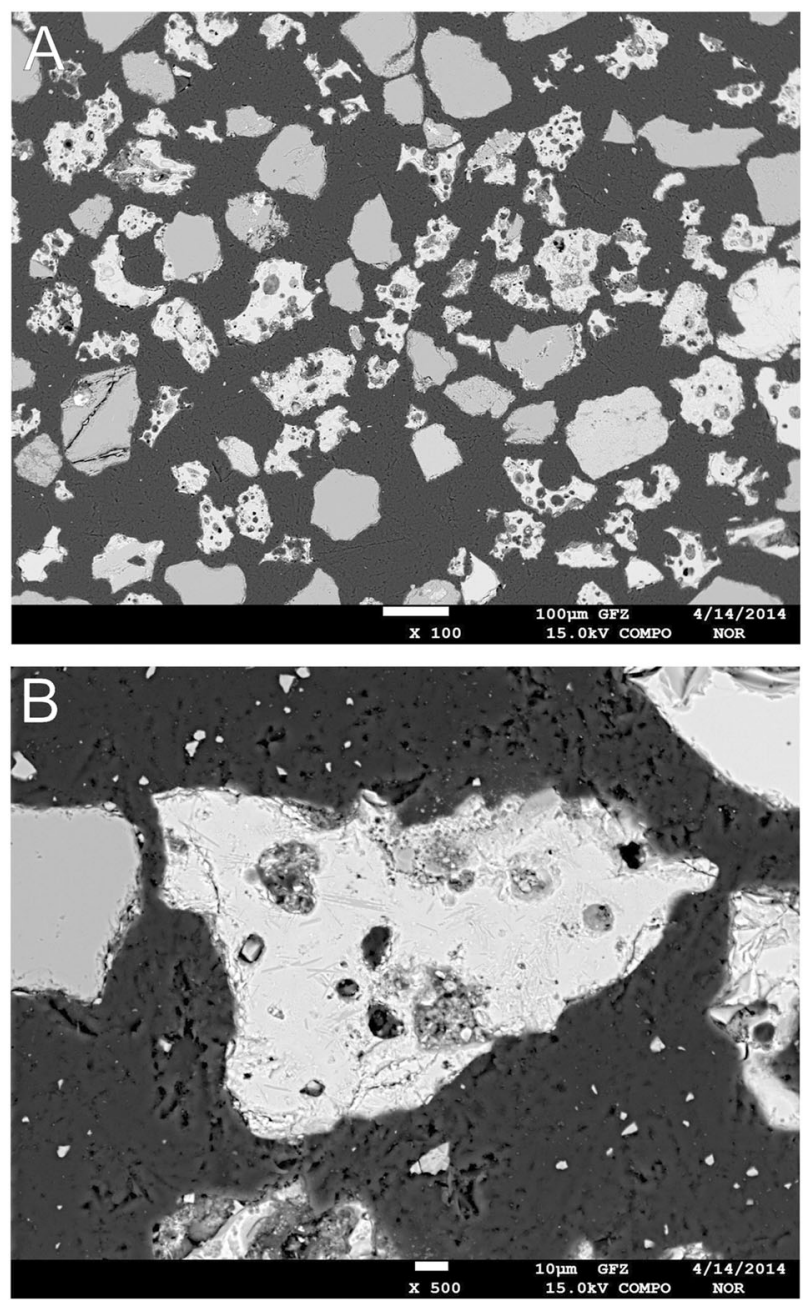

Figure 6 Scanning electron microscopy images of polished tephra grains in resin. (A) Tephra particles 100x magnification found at core depth 166-165 cm; (B) tephra particle 500x magnification found at core depth $156-155 \mathrm{~cm}$

(pH 7.1-7.9), slightly acid to moderately alkaline in unit D (pH6.3-7.9) and slightly to moderately alkaline in unit E ( $\mathrm{pH} 7.4-7.9)$. The EC of all porewaters was very low with 3-7 $\mu \mathrm{S} \mathrm{cm}^{-1}$. Only the uppermost sample at $2-1 \mathrm{~cm}$ yielded increased $\mathrm{EC}$ of $26.5 \mu \mathrm{S} \mathrm{cm}^{-1}$

A total of 75 samples equally distributed in all units were analysed for ostracods. Except for the uppermost unit E, all units lacked fossil remains of ostracods and molluscs pointing either to a non-lacustrine origin of sediments or to unfavourable living or preservation conditions. In unit $\mathrm{E}$, seven ostracod taxa were identified in four samples representing the uppermost $28 \mathrm{~cm}$ of the core (Figures 7, Figure 8; Table S2). The count numbers of valves per sample range from only six specimens at $28-27 \mathrm{~cm}$ up to 794 specimens at $22-21 \mathrm{~cm}$. The species Cypria ophtalmica, Candona ikpukpuensis and juvenile Candoninae (most likely representing juvenile stages of Fabaeformiscandina protzi) were found in all four samples. Adult $F$. protzi were

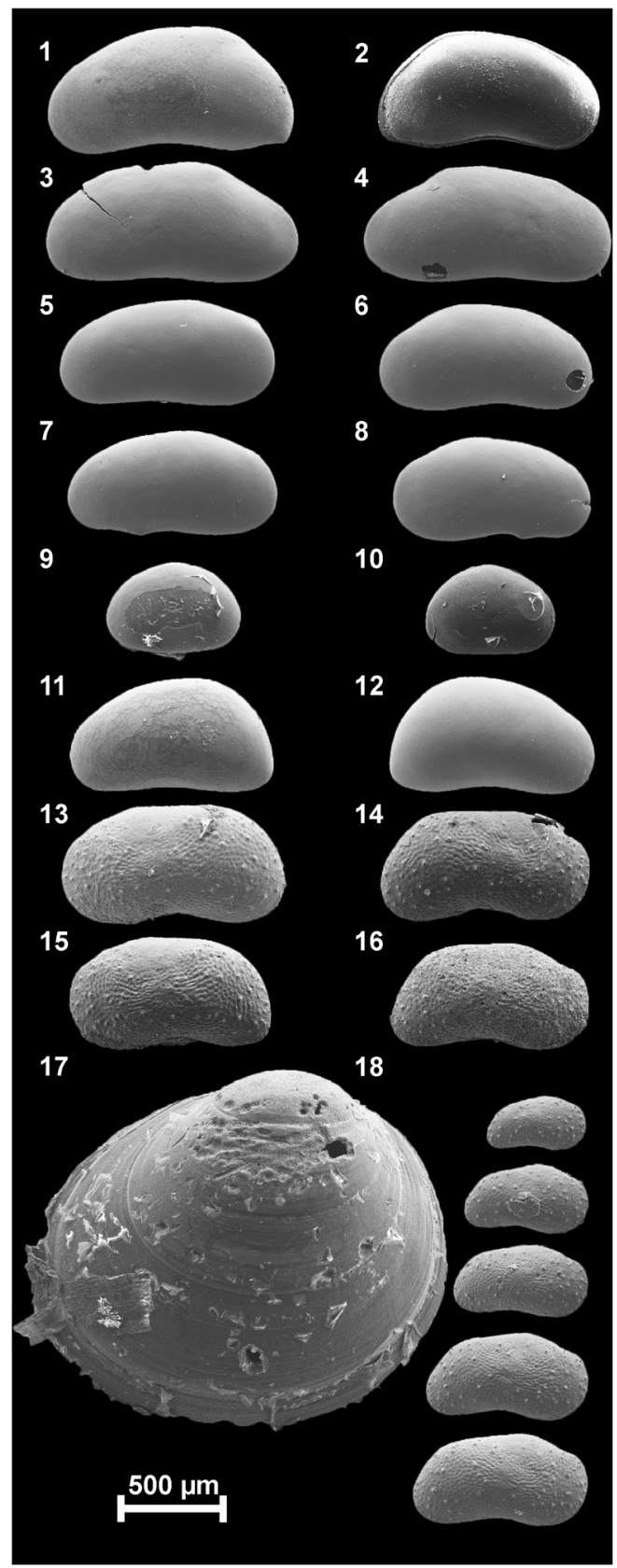

Figure 7 Scanning electron microscopy images of fossil ostracod valves and a mollusc shell. Fabaeformiscandona caudata: (1) female LV (Left Valve), (2) female carapace (RV (Right Valve) view); F. pedata: (3) female LV (Left Valve), (4) female RV (Right Valve); F. protzi: (5) male LV (Left Valve), (6) male RV (Right Valve), (7) female LV (Left Valve), (8) female RV (Right Valve); Cypria ophtalmica: (9) female LV (Left Valve), (10) female RV (Right Valve); Candona candida: (11) female LV (Left Valve), (12) female RV (Right Valve); Candona ikpukpuensis: (13) male LV (Left Valve), (14) male RV (Right Valve), (15) female LV (Left Valve), (16) female RV (Right Valve); Pisidia sp.: (17) valve; Candona ikpukpuensis: (18) juvenile RVs in five development stages.

observed in the upper $22 \mathrm{~cm}$. Here, single carapaces (both valves attached together) were documented. The findings of intact carapaces point to in-situ preservation of the 


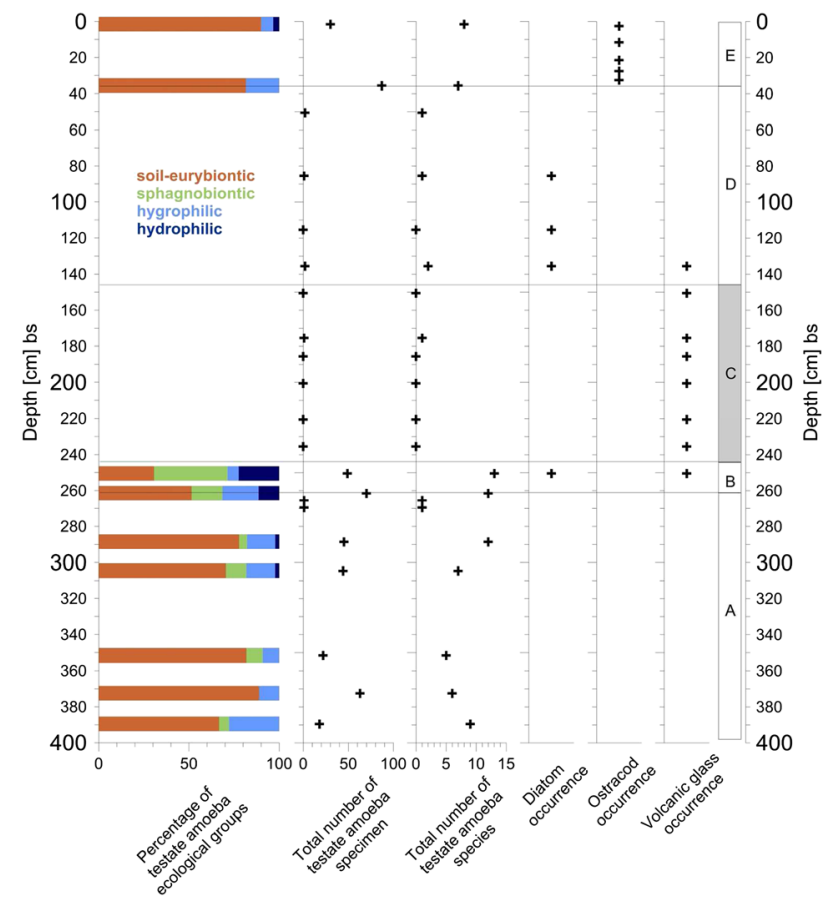

Figure 8 Total number of testate amoeba specimens and species, as well as occurrence of diatoms, ostracods and volcanic glass in sediment core Kit64. $\mathrm{Cm}$ bs = Centimetres below surface. This figure is available in colour online at wileyonlinelibrary.com/journal/ppp

lacustrine records. Female specimens of Candona candida and $F$. caudata are found only at $3-2 \mathrm{~cm}$ and $12 \mathrm{~cm}$ and $F$. pedata only at $3-2 \mathrm{~cm}$. Male specimens of these three species as well as of Cypria ophtalmica were lacking in the record. Both sexes were present for Candona ikpukpuensis and $F$. protzi. The species composition was clearly dominated by $F$. protzi; a species known as cold stenothermal that tolerates a wide range of ecological conditions of $\mathrm{pH}$ and salinity (Meisch, 2000). In modern subarctic and arctic environments, $F$. protzi is so far recorded in the Lena River Delta (Wetterich et al., 2008a) and the Indigirka Lowland (Schneider et al., in press) as well as in the Canadian Northwest Territories and the Alaskan Yukon (L. D. Delorme, unpublished data). A broad circumarctic distribution is known for Candona candida, a highly tolerant species (e.g. Alm, 1914; Røen, 1962, 1968; Havel et al., 1990; Wetterich et al., 2008a, 2008b; L. D. Delorme, unpublished data) while $F$. caudata, F. pedata and Cypria ophtalmica show more restricted occurrences in the Canadian subarctic for F. caudata (Havel et al., 1990) and in northeastern Siberia for F. pedata and Cypria ophtalmica (Sars, 1898; Wetterich et al., 2008a; Schneider et al., in press). Modern records of Candona ikpukpuensis are only known from the Alaskan Yukon (L. D. Delorme, unpublished data). However, modern ecological reference data on freshwater ostracods is generally still rare in subarctic and arctic regions and therefore of less use for the characterisation of Holocene thermokarst conditions. Except for $F$. pedata, fossil records of all species present in unit $\mathrm{E}$ as adult specimens are known from thermokarst deposits of Mid-Wisconsin to Holocene age from the Seward Peninsula (Wetterich et al., 2012). Therefore, the ostracod assemblage of unit E is assumed to represent local shallow-water thermokarst during the Holocene, which was most likely controlled by varying water levels due to summertime evaporation and consequently varying hydrochemical conditions (e.g. increasing ion content because of water loss) during the growing season of ostracods. The high ecological tolerance level of the dominant ostracod species ensured their survival under such conditions.

\section{Testate amoebae}

A total of 21 samples were analysed for the presence of testaceans. Out of these, six samples did not contain any testate amoebae and 15 samples yielded 39 testacean taxa of ten genera (Table S3). Specimen counts per sample varied between single finds and up to 87 (Figure 8). Four ecological groups were distinguished based on Chardez (1965) (Figure 8): hydrophilic (indicating waterlogged habitats), hygrophylic (indicating moist habitats), sphagnobiontic (typical inhabitants of Sphagnum moss) and soil-eurybiontic species (tolerating a wide range of a particular environmental factor, the specific factor (moisture, $\mathrm{pH}$, etc.) varies between species). The following species were found in three or more samples: Centropyxis aerophila v. major, Centropyxis sylvatica, Centropyxis sylvatica f. major, Cyclopyxis eurystoma and Plagiopyxis callida (all soil eurybiontic), Heleopera petricola (sphagnobiontic) and Centropyxis constricta (hygrophilic).

In unit A, soil-eurybiontic species of the genera Centropyxis, Cyclopyxis and Plagiopyxis dominated at $390 \mathrm{~cm}$. However, findings of large specimens of the soil-eurybiontic Centropyxis aerophila v. major and Centropyxis sylvatica f. (major) as well as the hydrophilic species Centropyxis constricta sensu lato and the sphagnobiontic species Arcella arenaria v. compress indicated generally moist conditions. At $372-352 \mathrm{~cm}$, sphagnobiontic species were lacking but the species composition still indicated overall moist conditions. At $305 \mathrm{~cm}$, specimen numbers of hydrophilic species Centropyxis cassis and Centropyxis constricta sensu lato increased indicating a higher degree of moisture. Ecological groups were similar at $289 \mathrm{~cm}$ but here also the hydrophilic species Centropyxis gibba occurred. At $270 \mathrm{~cm}$, only single specimen finds of soil-eurybiontic species indicated ecological conditions not favourable for testaceans.

A sharp change in ecological conditions occurred in unit B. All ecological groups were present and although soileurybiontic species dominated with $50 \%$, strictly hydrophilic species of the genus Difflugia also occurred which indicate very moist conditions. Samples from the tephra-dominated unit $\mathrm{C}$ contained only one observed testacea. In unit $\mathrm{D}$, only four soil-eurybiontic species with one specimen each were found. In unit E, high testacean numbers were observed at $36 \mathrm{~cm}$. Here, mainly soil-eurybiontic species from the genera Centropyxis, Cyclopyxis and Plagiopyxis were found but also 
the hygrophilic species Centropyxis constricta and the calceophilic, soil-eurybiontic species Centropyxis plagiostoma. Cyclopyxis kahli showed moisture enrichment in biophilic elements right above the permafrost table. The same ecological groups but with different species were identified at $2-1 \mathrm{~cm}$.

\section{Other Fossil Remains}

In unit A, a sponge needle occurred at $266-265 \mathrm{~cm}$. Within unit B, benthic alkaphilic diatoms of the species Hantzschia amphioxys and Navicula elginensis were found at $251-250 \mathrm{~cm}$. No diatoms were found in samples from unit C. In unit D same diatom species were found at $136-135 \mathrm{~cm}$ as in unit A as well as occasional benthic diatom species N. elginensis and Pinnularia brevicostata. Mollusc remains of Pisidia sp. were found in the upper $22 \mathrm{~cm}$ of unit E.

\section{Geochronology}

According to the results of 16 AMS radiocarbon determinations, the sediment core covered at least the last 49 000 years (including age inversions and a hiatus between 22.5 and $0.23 \mathrm{ka} \mathrm{BP}$ ) and allowed a chronological classification of landscape development stages (Figures 4 and 5; Table 2). Out of six-dated plant macrofossils in unit $A$, three had infinite ages and two more exceeded the range of current radiocarbon calibration curves. Age inversions in this unit are disregarded due to the large errors of up to 2000 years and the general limitations of ages close to the methodological limits of radiocarbon dating. An overall age span of $>49$ to $44.1 \pm 1.0 \mathrm{ka} \mathrm{BP}$ was assumed for unit $\mathrm{A}$, placing this unit most likely into the Early to Mid-Wisconsin. According to two radiocarbon dates of $44.5 \pm 2.0 \mathrm{ka} \mathrm{BP}(264-263 \mathrm{~cm})$ and $41.5 \pm 1.5 \mathrm{ka} \mathrm{BP}(251-250 \mathrm{~cm})$, unit $\mathrm{B}$ was dated to the Mid-Wisconsin. Unit $\mathrm{C}$ provided two radiocarbon ages of $46.5 \pm 3.5 \mathrm{ka} \mathrm{BP}(197-196 \mathrm{~cm})$ and $31.1 \pm 0.5 \mathrm{ka} \mathrm{BP}$ $(187-186 \mathrm{~cm})$ and fell in the Mid-Wisconsin. Unit D was dated with four samples and no age inversion between $36.5 \pm 0.5 \mathrm{ka}$ BP $(141-140 \mathrm{~cm})$ and $22.5 \pm 0.16 \mathrm{ka} \mathrm{BP}$ $(37-36 \mathrm{~cm})$, placing this unit in the transition phase from the Mid to Late-Wisconsin. In unit E, ages included 0.23 $\pm 0.03 \mathrm{ka} \mathrm{BP}(28-27 \mathrm{~cm})$ and $6.3 \pm 0.04 \mathrm{ka} \mathrm{BP}(3-2 \mathrm{~cm})$, representing the Holocene deposition of lacustrine sediments and reworking of older organic material from shore erosion processes. An overall age of $290 \pm 0.02$ cal a BP will be discussed for unit $\mathrm{E}$. The age inversion in this unit was likely caused by redeposition of terrestrial organic matter as commonly described in thermokarst lake sediments (Murton, 1996; Wetterich et al., 2011; Biskaborn et al., 2013a; Kanevskiy et al., 2014).

\section{DISCUSSION}

Our results from core Kit-64 allowed the interpretation of various landscape development stages in the study region for an approximately 50000 year period (Figure 9).

\section{Early to Mid-Wisconsin Deposition of Yedoma and Mid-Wisconsin Thaw (Unit A)}

Fine-grained sediments with interbedded organic-rich material in unit A represent yedoma deposits that most likely accumulated during the Early to Mid-Wisconsin from $>49$ to $45 \mathrm{ka} \mathrm{BP}$. Based on the experience that Pleistocene depositional areas in unglaciated regions of Beringia often have long continuous sedimentary records, we assume that unit A despite the presence of infinite ages is an immediate stratigraphic predecessor of unit B without hiatus. Although yedoma is a prominent feature of the modern terrestrial unglaciated Arctic of Eurasia and North America (Froese et al., 2009; Kanevskiy et al., 2011; Strauss et al., 2012; Schirrmeister et al., 2013), it only constitutes remnants of the Pleistocene depositional landscape (Grosse et al., 2013b). Here, syngenetic ice-rich permafrost developed concurrently with primarily silt sedimentation under cold and severe climate conditions (Kanevskiy et al., 2011). Although aeolian deposition is assumed to be an important component of yedoma sediment accumulation, other processes such as nival, alluvial and even fluvial and lacustrine processes have contributed to yedoma deposition in the Arctic (Strauss et al., 2012; Schirrmeister et al., 2013). In our record, sediments are dominated by the silty grain size fraction; thus, primary aeolian deposition and secondary redeposition of aeolian and nival weathering material may have contributed most of the sediment. These processes in turn reflect Beringia's high continentality due to sea-level low stands which resulted in generally cold and dry conditions during this time (Hopkins, 1967; Kaufman and Hopkins, 1986). In contrast to the proposed high continentality, less aridity during the LGM was suggested by pollen and insect records from areas adjacent to the Bering Land Bridge (Elias et al., 1997; Ager, 2003); steppetundra conditions were evident from mammoth remains dated to $>39 \mathrm{ka} \mathrm{BP}$ in central Alaska and $27 \mathrm{ka} \mathrm{BP}$ on Baldwin Peninsula east of the Seward Peninsula (Hopkins et al., 1976). Organic matter accumulated in permafrost soils under harsh ice age conditions and was only weakly decomposed as it became integrated into permafrost by the seasonally thawing active layer. Unit A of Kit-64 exhibits a mean TOC of $7.6 \mathrm{wt} \%$ which is relatively high compared to the studies of Strauss et al. (2013) $(3.0+1.6 /-2.2 \mathrm{wt} \%)$, Kanevskiy et al. (2011) (2.8-8.2\% in the active layer and $0.01-1.7 \%$ in the permafrost) and Zimov et al. (2006) (2-5\%). In unit A, several organic-rich sections, previously also described for other yedoma sites (Schirrmeister et al., 2008, 2011, 2013), increase the mean TOC value significantly. The inclusions and layers of well-decomposed organic matter contain single pieces of woody remains up to $1 \mathrm{~cm}$ in length. These layers have a maximum TOC content of $34.5 \mathrm{wt} \%$, whereas a minimum TOC content of $1.3 \mathrm{wt} \%$ is found in the mineral sections of unit $\mathrm{A}$. The large range indicates the high variability of primary productivity during deposition. In addition, unit A experienced complete thaw and beginning transformation into a taberite under the former thermokarst lake (unit E), hence we expect that 
J. Lenz et al.

\section{Evolution of GG Basin}

Modern

lake drainage

Spring 2005

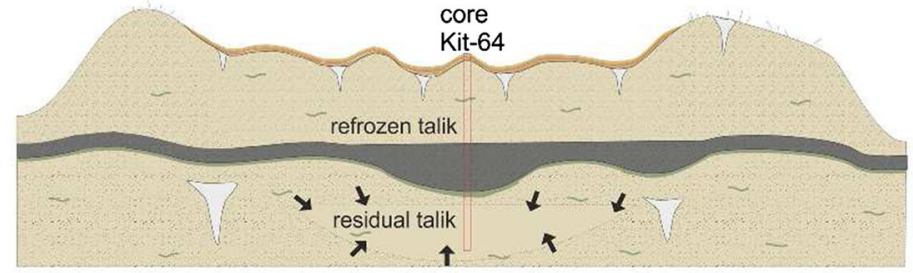

Unit E

Late Holocene thermokarst lake 0.3-0 ka BP

\section{Unit D/E}

Late-Wisconsin

to Holocene

hiatus

22.5-0.3 ka BP
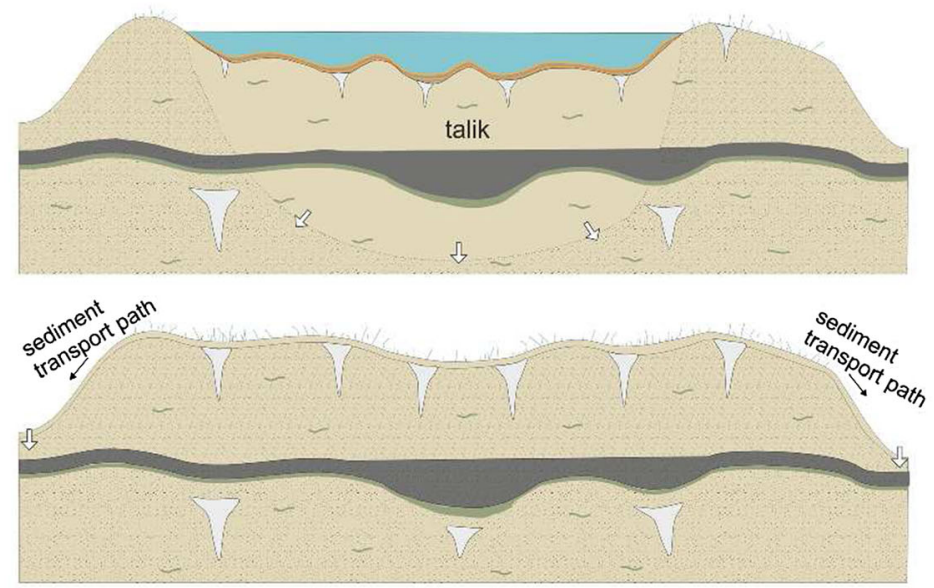

\section{Unit D \\ Mid to \\ Late-Wisconsin \\ yedoma \\ accumulation \\ 36.5-22.5 ka BP}

Unit C

South Killeak

Maar eruption

$\sim 31.1-46.5 \mathrm{ka} \mathrm{BP}$
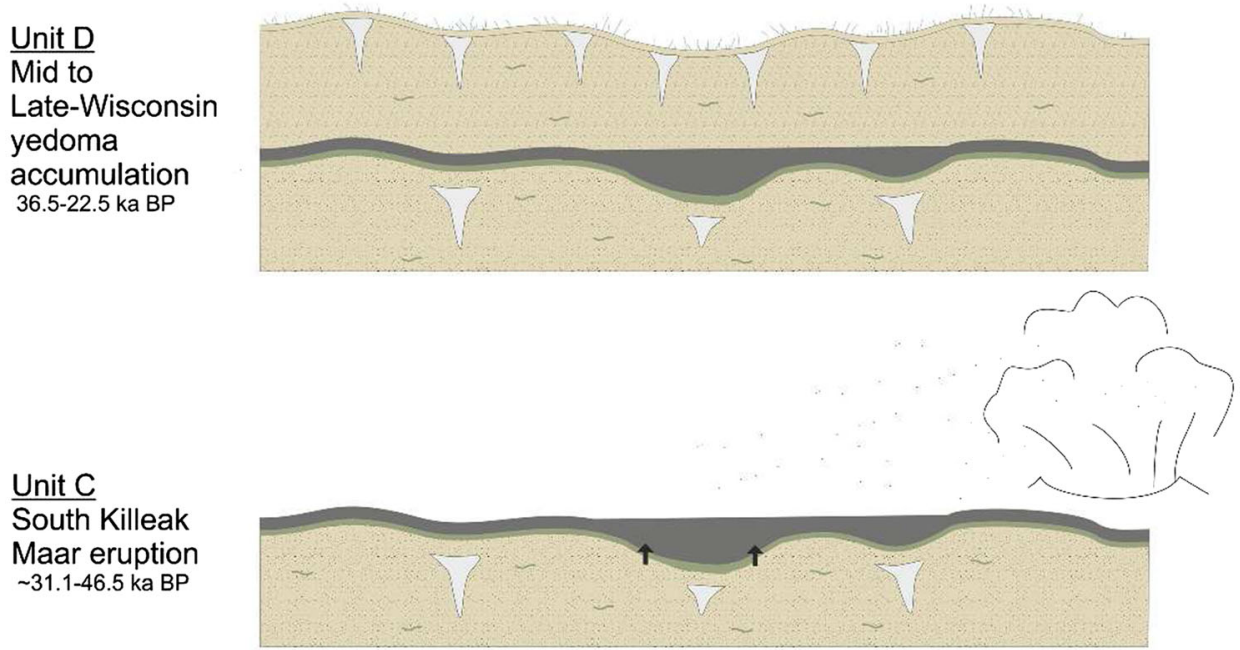

Unit B

Mid-Wisconsin wetland to early thermokarst $\sim 44.5-41.5$ ka BP

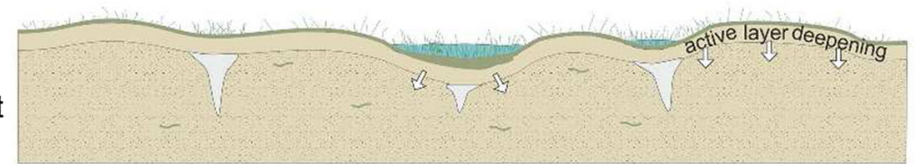

Unit A

Early to Mid-Wisconsin yedoma accumulation $>44$ ka BP

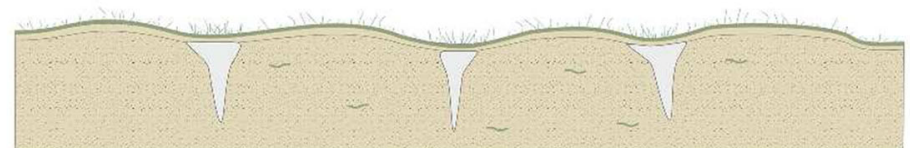

Figure 9 Schematic evolution of GG basin. See text for abbreviation. This figure is available in colour online at wileyonlinelibrary.com/journal/ppp 
portions of the originally present carbon were decomposed. However, the TOC data are within the range of previously reported possible values for yedoma (Schirrmeister et al., 2013; from $<1$ to $>20 \mathrm{wt} \%$ in 700 analyses from 14 Siberian sites). Organic-rich layers in unit A demonstrate the potential for soil development under Mid-Wisconsin conditions. The marbled sediment structure of unit A points towards soil cryoturbation at the time when the sediment was frozen. Additionally, rhizopods indicate an intermittent wet, but still terrestrial environment since soil-eurybiontic and hygrophilic species dominate but hydrophilic rhizopods are present in the organic-rich layers of the upper part of the unit. Syngenetic freezing of organic-rich sediments resulted in significantly slowed decomposition, forming an effective long-term organic carbon sink (Strauss et al., 2013).

Unit A was recovered almost completely unfrozen (only the uppermost $4 \mathrm{~cm}$ of the $125 \mathrm{~cm}$ long unit were frozen), indicating the impact of deep thaw under the lake of unit $\mathrm{E}$ and subsequent slow refreezing after this lake drained. Melt out of ground ice including large syngenetic yedoma ice wedges caused a significant loss of volume and ground subsidence. The sediment of unit A is therefore considered as a diagenetically altered (thaw, compaction in a talik) yedoma deposit also known as taberite (Romanovskii, 1993; Walter Anthony et al., 2014).

\section{Mid-Wisconsin Wetland (Unit B)}

The terrestrial yedoma deposition of unit A is followed by a clear wet phase (unit B) dated to $44.5 \pm 2.0 \mathrm{ka}$ BP to 41.5 $\pm 1.5 \mathrm{ka} \mathrm{BP}$ forming a wetland or shallow pond as indicated by hydrophilic rhizopod communities. Single diatoms were observed, although ostracods were not present. Either ostracods were not preserved in the peaty deposits of unit B due to acidic conditions as measured in porewaters with a $\mathrm{pH}$ of 5.4-5.6 or living conditions in the Mid-Wisconsin were unfavourable. Poor preservation conditions for ostracod calcite in acidic peaty sediments of lacustrine origin were previously reported, for example, by Wetterich et al. (2005). Higher TOC contents of $29-35.4 \mathrm{wt} \%$ in unit B point to higher bioproductivity, possibly signalling climate amelioration during that part of the Mid-Wisconsin. The highest $\mathrm{C} / \mathrm{N}$ ratio in the core of 19 was calculated for unit $\mathrm{B}$ indicating a low degree of decomposition. In combination with relatively low $\delta^{13} \mathrm{C}$ values of -28.7 to $-27.3 \%$, it is evident that terrestrial plants from the surrounding catchment are the most likely source of the organic matter (Meyers, 1994; Meyers and Lallier-Verges, 1999).

Unit B demonstrates intermediate wet conditions allowing the formation of wetlands or initial ponding. Hopkins and Kidd (1988) interpreted lacustrine sequences on exposures along the Seward Peninsula coast as Wisconsin-age thermokarst lakes. Radiocarbon-dated evidence for MidWisconsin thermokarst lake development in central Beringia was provided by Wetterich et al. (2012). Here, lacustrine sediments as well as fossils of freshwater molluscs and ostracods indicate that a lake persisted until about $32 \mathrm{ka} \mathrm{BP}$.
Various studies in eastern Beringia based on vegetation distribution and summarised by Anderson and Lozhkin (2001) indicate spatially complex but regional warmer temperature conditions during the Mid-Wisconsin. For example, herb Betula-Salix low-shrub tundra at $39 \mathrm{ka}$ BP suggesting temperatures warmer than during glacial times but still much cooler than present in the Yukon Territory. However, Beringia was climatically and environmentally heterogeneous due to the effect of boundary conditions like insolation, meteorological conditions, distribution of ice sheets and sea surface temperatures (Anderson and Lozhkin, 2001).

\section{South Killeak Maar Eruption and Tephra Fall-Out (Unit C)}

Because of its age constrain between $46.5 \pm 3.5 \mathrm{ka}$ BP and $31.1 \pm 0.5 \mathrm{ka} B P$, we suggest that the Kit-64 tephra most likely coincides with the $42 \mathrm{ka}$ South Killeak Maar eruption (Hopkins, 1988; Begét et al., 1996). From this chronological evidence, we exclude a correlation with the much younger Devil Mountain Maar tephra (18.0 ka BP). Unfortunately, we are not able at this stage to strengthen this correlation by the comparison of tephra compositions due to the lack of glass chemical data in the literature. Both the South Killeak and Devil Mountain Maar tephras are in general described as basaltic air fall products of phreatomagmatic eruptions, which are known to be extraordinarily explosive because frozen (solid) water in permafrost is rapidly transformed to the gas phase (e.g. Hopkins, 1988; Begét et al., 1996). Our data provide the first geochemical data-set of the South Killeak Maar tephra (Table 3). Previously, several studies focused on investigations of a palaeosol buried by the younger Devil Mountain Maar tephra (Höfle and Ping, 1996; Höfle et al., 2000; Goetcheus and Birks, 2001; Kuzmina et al., 2008) but geochemical data of this and other tephra layers have not been reported so far. As tephra layers are important stratigraphic markers, the geochemical glass data of the Kit-64 tephra can be of great value for future palaeoenvironmental investigations in the region.

The $1 \mathrm{~m}$ thick air-fall tephra associated with the South Killeak Maar eruption at about $42 \mathrm{ka}$ BP interrupted and abruptly terminated the wetland development at our site (unit B). The abrupt change of facies from unit $\mathrm{B}$ to $\mathrm{C}$ is not only evident in the lithology but also in the high MS signals, low biogenic deposition, high accumulation of clastic material greater than $0.063 \mathrm{~mm}$ up to occasional $7 \mathrm{~mm}$ grain size, as well as isotopic enrichment in $\delta^{13} \mathrm{C}$. The absence of rhizopods, diatoms and ostracods points towards unfavourable living conditions or, alternatively, very rapid deposition of the entire unit. It can be assumed that the wetland or initial pond was entirely covered by tephra. Apparently, the South Killeak Maar eruption had a significant influence on the regional wetland and pond development and thus may have substantially changed the local to regional landscape evolution by filling and levelling terrain depressions. 


\section{Continued Yedoma Accumulation during the Mid to Late-Wisconsin (Unit D)}

The initial Mid-Wisconsin wetland or shallow pond did not recover after the fall-out of the South Killeak Maar tephra but terrestrial silty sediment accumulated with intermediate organic layers within a time span of $36.5 \pm 0.5 \mathrm{ka}$ BP to 22.5 $\pm 0.16 \mathrm{ka}$ BP. The sedimentological and biogeochemical properties of these yedoma deposits are similar to those in unit A. Four findings of a soil-eurybiontic testate amoeba species indicate a generally cold and dry depositional environment. No ostracods but the occasional presence of diatoms were reported which is not unusual in yedoma deposits as proven by molecular biomarkers (occurrence of brassicasterol, J. Strauss, personal communication; detected in Siberian yedoma, Strauss et al., 2014) indicating seasonally wet phases.

\section{Late-Wisconsin to Late Holocene Hiatus (Transition from Unit D to Unit E)}

At $36 \mathrm{~cm}$, a change of facies is noted and its transition was bracketed by radiocarbon dates of $22.5 \pm 0.16 \mathrm{ka}$ BP below the boundary and $0.23 \pm 0.03 \mathrm{ka}$ BP above the boundary from unit $\mathrm{D}$ to unit $\mathrm{E}$. We hypothesise that this apparent hiatus of sedimentation may be explained either by a lack of deposition during the Lateglacial and Holocene or by Early Holocene thermokarst-related erosion of surficial deposits at the study site. Both scenarios have been suggested as a responsible mechanism for a depositional hiatus during this period in other studies of yedoma and thermokarst profiles of northern Siberia (Grosse et al., 2007; Andreev et al., 2009).

In our hypothetical scenario, after syngenetic permafrost accumulation during the Mid to Late-Wisconsin, a period of massive thermokarst initiated in the region. Deep and widespread permafrost thaw is suggested in various datasets from northwest North America and Siberia which propose strong postglacial warming and peaking at the onset of the Holocene Thermal Maximum (HTM) (McCulloch and Hopkins, 1966; Burn et al., 1986; Rampton, 1988; Burn and Smith, 1990; Burn, 1997; Kaufman et al., 2004; Walter et al., 2007; Wetterich et al., 2012; Fritz et al., 2012; Lenz et al., 2013; Morgenstern et al., 2013; Schleusner et al., 2015). Alaska and the western Canadian Arctic warmed earlier $(11.3 \pm 1.5 \mathrm{cal} \mathrm{ka}$ BP) than continental Canada and the Canadian Arctic Archipelago (7.3 $\pm 1.6 \mathrm{cal}$ ka BP) due to the cooling influence of the Laurentide Ice Sheet (Kaufman et al., 2004). Although timing of the HTM varied spatially, an increase in mean summer temperature of $1.6 \pm 0.8^{\circ} \mathrm{C}$ compared to average $20^{\text {th }}$ century is assumed for the North American Arctic (Kaufman et al., 2004). Rapid thermokarst formation in the study region resulted in dissection of the yedoma uplands which is evident from the general geomorphology of the region. Yedoma remnants were carved out and persisted as smaller uplands until modern times while thermokarst lakes now dominate the lowlands (see also Figure 2). Kanevskiy et al. (2014) stated that the process of reducing yedoma to isolated remnant hills by thermokarst lake development can take thousands of years. In this case, the yedoma upland of the modern GG basin (Figure 2) served as a sediment source and parts of the potentially present LateWisconsin deposits were eroded. This phase of intense thermokarst activity, indicating warmer and wetter climate conditions in the Late-Wisconsin and Holocene, is not resolved in our record by sedimentation but indicated by a depositional hiatus. Thus, neither the LGM nor the prominent Devil Mountain Maar tephra was archived in the record of core Kit-64.

\section{Late Holocene Thermokarst Lake (Unit E)}

A lake phase forming GG basin evidently started about 300 years ago $(0.23 \pm 0.3 \mathrm{ka} \mathrm{BP}$ or $290 \pm 0.02 \mathrm{cal}$ a BP at $28-27 \mathrm{~cm})$ as suggested by distinct laminations and mollusc shells as well as a well-preserved ostracod assemblage indicating a cold freshwater, shallow-water ecosystem. The cause for the lake initiation is difficult to access based on a single core alone, but we speculate that local disturbances of the ground thermal regime rather than a broader climatic signal were the most likely cause. The high ecological tolerance of ostracods present allowed them to live in altering hydrochemical conditions during the Late Holocene. At the lower boundary of unit E, increased bioproductivity of the initiating shallow lake is signalled by higher TN, TC and TOC. A C/N ratio of 14 indicates a poor decomposition of organic matter in the early phase. Testate amoeba point towards a shift from terrestrial wet to aquatic conditions; so does the ratio of $\delta^{13} \mathrm{C}$ and $\mathrm{C} / \mathrm{N}$ ratio. The $\mathrm{EC}$ of porewater is as low as in the rest of the frozen core but increased at the sediment surface to $26.5 \mu \mathrm{S} \mathrm{cm}^{-1} \mathrm{~T}_{25^{\circ}}$ indicating sublimation processes at the surface which were also evident in the field by a salty crust.

The presence of a thermokarst lake is visible in a series of aerial and satellite images taken in 1950, 1978, 2004 and 2005 (Figure 10). In 1980, GG lake had a mean water depth of $12 \mathrm{~m}$ and a surface area of 7.9 ha (Table 1).

Jones et al. (2011) analysed high-resolution remotely sensed imagery to determine thermokarst lake expansion rates on the northern Seward Peninsula between the early 1950s and mid-2000s. Thermokarst lakes surrounded by yedoma terrain typically have lake bluff heights that range from $6-17 \mathrm{~m}$ and erosion rates of $0.15-0.18 \mathrm{~m} \mathrm{a}^{-1}$ over this time period. Between 1950 and 1978, the lake that formerly occupied GG basin decreased in surface area by 0.2 ha indicating that the lake may have started to drain slightly during this period. While the shoreline receded around much of the lake perimeter, the lake eroded towards the outlet and eventual drainage gully location at a rate of $\sim 0.20 \mathrm{~m} \mathrm{a}^{-1}$. The 1978 aerial photograph also revealed substantial erosion $(\sim 30 \mathrm{~m})$ along the drainage gully relative to the 1950 aerial photograph. There is a lack of 


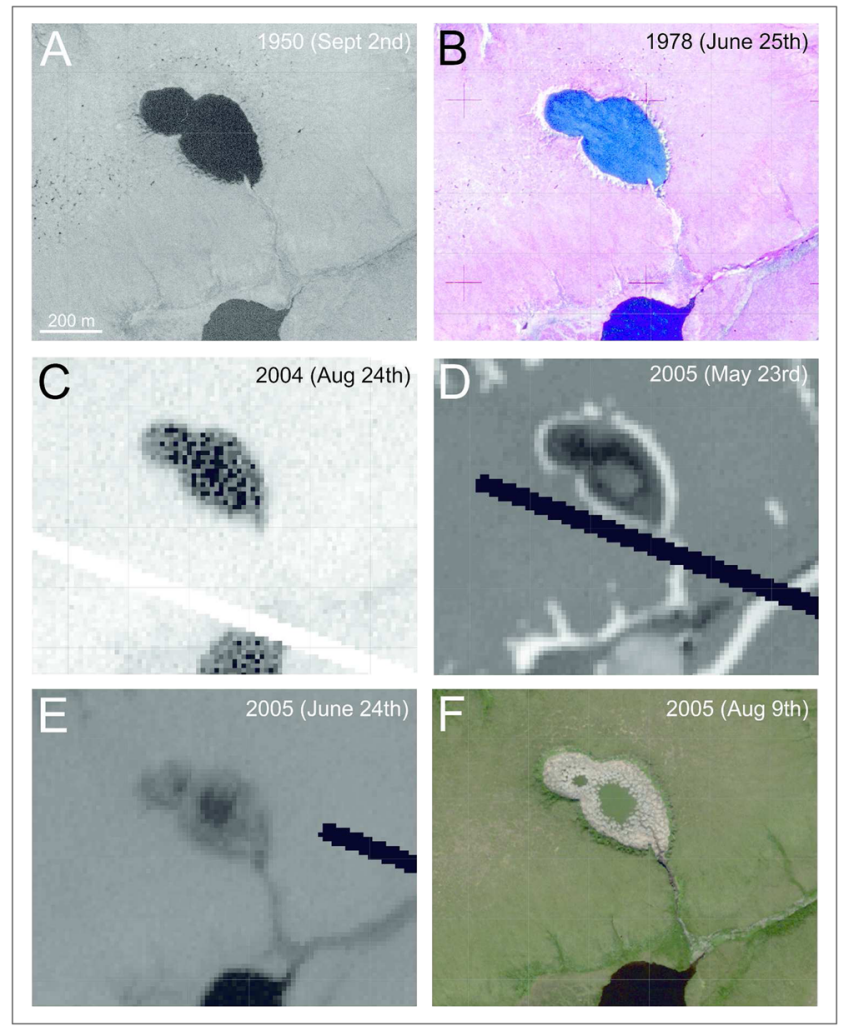

Figure 10 Time series of remote sensing imagery of the study area: (A) Black and white aerial image (2 Sep 1950); (B) colour infrared aerial image (25 Jun 1978); (C) Landsat Enhanced Thematic Mapper (ETM)+panchromatic satellite image (24 Aug 2004); (D) Landsat ETM+panchromatic satellite image (23 May 2005); (E) Landsat ETM+panchromatic satellite image (24 June 2005); (F) Quickbird satellite image (9 Aug 2005).

high-resolution remotely sensed imagery following the 1978 image and prior to the drainage of the lake that occupied GG basin. The presence of baydzherakhs on the lake floor (Figures 3 and 10) indicates that GG lake was a first-generation thermokarst lake. The presence of baydzherakhs also suggests that not much surface sediment was removed during the drainage event. The sediment core, taken from the top of a baydzherakh, had only $36 \mathrm{~cm}$ of lake sediment. Cross-sections of thermokarst lake deposits on the Seward Peninsula show highly variable lacustrine sediment thicknesses with thicker sediment packages in the troughs between baydzherakhs and thinner lake sediments on top of baydzherakhs (G. Grosse, unpublished data).

The water volume of GG lake was calculated to about 0.7 million $\mathrm{m}^{3}$ for the year 1980 . With about $12 \mathrm{~m}$ water depth in 1980 (Table 1), GG lake was deep enough to prevent lake ice grounding. Therefore, this young lake must already have had a substantial thaw bulb or talik which is a body of unfrozen ground due to a local anomaly in thermal, hydrological, hydrogeological or hydrochemical conditions (Van Everdingen, 2005).

\section{Late Holocene Lake Drainage and Basin Development since Spring $2005 \mathrm{AD}$}

Landsat imagery shows that the lake likely drained catastrophically between May and June 2005 (Figure 10): On 23 May 2005, the lake was largely ice-free but a residual ice cover was still present in the centre of the larger basin. On 24 June 2005, the lake had already drained except for a small remnant pond.

Whereas GG basin has mean bluff heights of $7.5 \mathrm{~m}$ and maximum heights of $20 \mathrm{~m}$, up to $40 \mathrm{~m}$ of thaw settlement were observed for yedoma deposits in central Yakutia (Czudek and Demek, 1970). Kessler et al. (2012) described a thermokarst lake system forming in yedoma on the northern Seward Peninsula near our study site with a total thaw settlement of $20-30 \mathrm{~m}$ similar to GG basin. Based on the digital elevation model (DEM), about 1.6 million $\mathrm{m}^{3}$ volume loss was caused by thawing of yedoma during the lake formation of GG basin (Table 1).

The net surface area of lakes on the northern Seward Peninsula decreased between $1950 / 51$ and $2006 / 07$ by 14.9 $\%$ (Jones et al., 2011) due to the drainage of several large lakes. Jones et al. (2012) described a high number of drainage events within the last 4000 years, especially during the medieval climate anomaly. Peat most rapidly accumulated with $35.2 \mathrm{~g} \mathrm{C} \mathrm{m}^{-2} \mathrm{a}^{-1}$ in the youngest basins which drained 50-500 years ago. In general, thermokarst lake basins in the Cape Espenberg lowlands of the northern Seward Peninsula (covering 76\% of the surface) are thought to store 6.4-6.6 $\mathrm{Tg}$ organic carbon in their terrestrial peat (Jones et al., 2012). Drained in spring 2005, no substantial vegetation cover had re-occupied the floor of GG basin in 2009 when coring took place. Post-drainage succession will likely result in vegetation re-occupation of the basin over the next years and possibly will result in slow peat accumulation. However, unlike the very wet lowland basins in our study region described in Jones et al. (2012) or on the Barrow Peninsula by Zona et al. (2010), gross primary productivity might stay low in the well-drained upland of GG basin. Since permafrost redeveloped within 4 years from the surface down to $268 \mathrm{~cm}$ in April 2009, it can be assumed that the formation of a new lake is not yet in progress but that the existing ponds are remnants of GG lake. Regmi et al. (2012) stated that the succession of a thermokarst lake in an old drained basin is dependent not only on climate variability but also basin topography and hydrology, the amount of ice content, the rate of vegetation succession and polygonal development.

Modern permafrost aggradation is discussed in the literature primarily in the context of development after local lake drainage. The prominent Illisarvik lake drainage experiment in 1978 by Ross Mackay revealed evidence for rapid reaggradation of permafrost (Mackay, 1997). The up to $32 \mathrm{~m}$ deep talik of Illisarvik lake refroze down to 5-6m within 2 years after drainage, whereas nearshore sites of $\leq 10 \mathrm{~m}$ were already completely refrozen (Burgess et al., 1982). Mean summer subsidence of the Illisarvik basin decreased during the first 8 years from 10 to $3 \mathrm{~cm}$ before winter frost heave and summer subsidence stabilised. Here, change in 
snow depth associated with vegetation growth is assumed to be the dominant control on variation of active layer depth (Mackay and Burn, 2002). Growth of aggradational ice of $0.5 \mathrm{~cm} \mathrm{a}^{-1}$ has been recorded 20 years after the experiment took place (Mackay and Burn, 2002).

Every year approximately 0.3 to two lakes drain in different regions in Arctic North America (northern Seward Peninsula: Jones et al., 2011; North Slope: Hinkel et al., 2007; northwest Canada: Marsh et al., 2009). Lateral drainage can be triggered by a number of geomorphological and hydrological processes such as bank over-topping as a result of heavy precipitation events, gully erosion through ice-wedge networks or tapping by rivers, lakes and coastal erosion (Hinkel et al., 2007; Marsh et al., 2009; Grosse et al., 2013a; Jones and Arp, 2015). The lateral drainage of GG lake was likely caused by an increased inflow into the lake from snowmelt and eventually by an overflow at the outlet channel that resulted in down-cutting into the ice-rich permafrost and promoting the drainage of the lake.

\section{CONCLUSIONS}

A sediment core record from a drained lake basin allowed us to reconstruct Mid-Wisconsin to Holocene landscape dynamics for this region typical of central Beringia. The following conclusions can be drawn:

(1) A multi-proxy approach allowed the determination of complex landscape interactions in a changing Arctic system affected by permafrost.

(2) Yedoma deposition prevailed throughout the Early to Mid-Wisconsin with intermediate wet conditions by about 44.5 to $41.5 \mathrm{ka}$ BP. Here, initial permafrost thaw began as indicated by wetland or potentially shallow pond formation but was terminated by the deposition of a thick air-fall tephra, most likely originating from the South Killeak Maar eruption at about $42 \mathrm{ka}$ BP. A depositional hiatus in our core between 22.5 and $0.23 \mathrm{ka} \mathrm{BP}$ was interpreted as a signal of strong landscape changes and local erosion associated with thermokarst development in the areas surrounding our yedoma upland site during the Lateglacial to Holocene. Following this period, our study site served as a sediment source for surrounding large thermokarst lakes and basins rather than an accumulation area until the formation of a small thermokarst lake on the upland about 300 years ago. This expanding and deepening lake drained catastrophically in spring 2005 as indicated by remote sensing data, leaving behind a so far largely barren drained thermokarst lake basin in which permafrost has just started to aggrade again.

(3) Permafrost formation, as well as degradation, in our study region in central Beringia over the last $49 \mathrm{ka}$ was controlled by regional to global climate patterns impacting processes (syngenetic permafrost formation during the Early to Late-Wisconsin; wetland formation during short warmer and wetter phases of the MidWisconsin; Lateglacial and early Holocene spread of thermokarst development) as well as local disturbances (wetland and pond burial during a Mid-Wisconsin tephra deposition event caused by a nearby phreatomagmatic maar lake eruption; thermokarst lake formation during the Late Holocene; sudden lake drainage in 2005).

\section{ACKNOWLEDGEMENTS}

We thank the National Park Service (NPS) for permitting research in the Bering Land Bridge National Preserve and L. McFadden for help in the field. We thank L. Farquharson, A. Myrbo and other colleagues from the National Science Foundation (NSF)-sponsored LacCore facility at the University of Minnesota for facilitating core splitting and GEOTEK scanning. Further, we would like to thank H. Kemnitz, I. Schäpan and O. Appelt (GFZ) for facilitating the SEM imaging as well as the geochemical analyses of tephra. R. Zibulski helped with the determination of radiocarbon-dated plant macrofossils. Laboratory assistance was provided by U. Bastian, A. Eulenburg, L. Schönicke and H. Meyer. Diatom species identification was thankfully undertaken by L. Pestryakova (North-eastern Federal University Yakutsk, Russia). We thank Jones for reviewing the manuscript.

The study contributes to the Arctic Ecological Network (Arc-EcoNet) funded by the German Federal Ministry of Education and Research (BMBF Grant No. 01DJ14003). Funding was provided by the NSF (ARC0732735), the NASA (NNX08AJ37G), the Western Alaska Landscape Conservation Cooperative (LCC) (WA2011-02) and a doctoral stipend by the University of Potsdam awarded to Josefine Lenz. Any use of trade, product, or firm names is for descriptive purposes only and does not imply endorsement by the US Government.

We thank Jef F. Vandenberghe, Mark Bateman and all guest editors of the special issue Reconstruction and modelling of paleo-permafrost as well as two anonymous reviewers who helped to improve the manuscript.

\section{REFERENCES}

Ager TA. 2003. Late Quaternary vegetation and climate history of the central Bering land bridge from St. Michael Island, western Alaska. Quaternary Research 60: 19-32.
Alm G. 1914. Beiträge zur Kenntnis der nördlichen und arktischen Ostracodenfauna. Arkiv för Zoologi 9: 1-20 (in German).

Anderson PM. 1985. Late Quaternary vegetational change in the Kotzebue Sound Area, northwestern Alaska. Quaternary Research 24: 307-321.
Anderson PM, Lozhkin AV. 2001. The Stage 3 interstadial complex (Karginskii/ middle Wisconsinan interval) of Beringia: variations in paleoenvironments and implications for paleoclimatic interpretations. Quaternary Science Reviews 20: 93-125. 
Andreev AA, Grosse G, Schirrmeister L, Kuznetsova TV, Kuzmina SA, Bobrov AA, Tarasov PE, Novenko EY, Meyer $\mathrm{H}$, Derevyagin AY, Kienast F, Bryantseva A, Kunitsky VV. 2009. Weichselian and Holocene palaeoenvironmental history of the Bol'shoy Lyakhovsky Island, New Siberian Archipelago, Arctic Siberia. Boreas 38: 72-110. DOI: 10.1111/j.1502-3885.2008. 00039.x. ISSN 0300-9483.

Arp CD, Jones BM. 2009. Geography of Alaska lake districts: Identification, description, and analysis of lake-rich regions of a diverse and dynamic state US Geological Survey Scientific Investigations Report. 2008-5215: 40pp.

Begét JE, Hopkins DM, Charron SD. 1996. The largest known maars on Earth, Seward Peninsula, northwest Alaska. Arctic 49: 62-69.

Berger GW, Anderson PM. 1994. Thermoluminescence dating of an Arctic lake core from Alaska. Quaternary Science Reviews 13(5-7): 497-501. DOI: 10.1016/02773791(94)90065-5

Biskaborn BK, Herzschuh U, Bolshiyanov DY, Savelieva L, Diekmann B. 2013a. Late Holocene thermokarst variability inferred from diatoms in a lake sediment record from the Lena Delta, Siberian Arctic. Journal of Paleolimnology 49: 155-170.

Biskaborn BK, Herzschuh U, Bolshiyanov DY, Schwamborn G, Diekmann B. 2013b. Thermokarst Processes and Depositional Events in a Tundra Lake, Northeastern Siberia. Permafrost and Periglacial Processes 24: 160-174.

Brown J, Ferrians O, Heginbottom J, Melnikov E. 2001. Circum-Arctic Map of Permafrost and Ground-ice Conditions. National Snow and Ice Data Center/World Data Center for Glaciology: Boulder, CO.

Burgess M, Judge A, Taylor A, Allen V. 1982. Ground temperature studies of permafrost growth at a drained lake site, Mackenzie Delta. In In Proceedings of 4th Canadian Permafrost Conference.

Burn CR. 1997. Cryostratigraphy, paleogeography, and climate change during the early Holocene warm interval, western Arctic coast, Canada. Canadian Journal of Earth Sciences 34: 912-925. DOI:10. 1139/e17-076.

Burn CR, Smith MW. 1990. Development of thermokarst lakes during the Holocene at sites near Mayo, Yukon Territory. Permafrost and Periglacial Processes 1: 161-176. DOI: $10.1002 /$ ppp.3430010207

Burn CR, Michel FA, Smith MW. 1986. Stratigraphic, isotopic, and mineralogical evidence for an early Holocene thaw unconformity at Mayo, Yukon Territory. Canadian Journal of Earth Sciences 23: 794-801. DOI:10.1139/e86-081.
Chardez D. 1965. Ecologie générale des Thécamoebiens. Bulletin de l'Institut Agronomique et des Stations de Recherche de Gembloux 33: 307-341.

Colinvaux PA. 1964. The environment of the Bering land bridge. Ecological Monographs 34: 297-329.

Czudek T, Demek J. 1970. Thermokarst in Siberia and its influence on the development of lowland relief. Quaternary Research 1: 103-120.

Elias SA, Short SK, Birks HH. 1997. Late Wisconsin environments of the Bering Land Bridge. Palaeogeography, Palaeoclimatology, Palaeoecology 136: 293-308.

Folk RL, Ward WC. 1957. Brazos River bar, a study in the significance of grain-size parameters. Journal of Sedimentary Petrology 27: 3-27.

French HM. 1974. Active Thermokarst Processes, Eastern Banks Island, Western Canadian Arctic. Canadian Journal of Earth Sciences 11: 785-794.

Fritz M, Wetterich S, Schirrmeister L, Meyer $\mathrm{H}$, Lantuit H, Preusser F, Pollard WH. 2012. Eastern Beringia and beyond: Late Wisconsinan and Holocene landscape dynamics along the Yukon Coastal Plain, Canada. Palaeogeography, Palaeoclimatology, Palaeoecology 319: 28-45. DOI:10.1016/j. palaeo.2011.12.015.

Froese DG, Westgate JA, Sanborn PT, Reyes AV, Pearce NJG. 2009. The Klondike goldfields and Pleistocene environments of Beringia. GSA Today 19(8): 4-10. DOI:10. 1130/GSATG54A.1

Gaglioti BV, Mann DH, Jones BM, Pohlman JW, Kunz ML, Wooller MJ. 2014. Radiocarbon age-offsets in an arctic lake reveal the long-term response of permafrost carbon to climate change. Journal of Geophysical Research, Biogeosciences 119: DOI: 10.1002/2014JG002688.

Goetcheus VG, Birks HH. 2001. Full-glacial upland tundra vegetation preserved under tephra in the Beringia National Park, Seward Peninsula, Alaska. Quaternary Science Reviews 20: 135-147.

Grosse G, Schirrmeister L, Siegert C, Kunitsky VV, Slagoda EA, Andreev AA, Dereviagyn AY. 2007. Geological and geomorphological evolution of a sedimentary periglacial landscape in Northeast Siberia during the Late Quaternary. Geomorphology 86: $25-51$.

Grosse G, Romanovsky VE, Jorgenson T, Walter Anthony KM, Brown J, Overduin PP. 2011. Vulnerability and feedbacks of arctic permafrost to climate change. Eos, Transactions of the American Geophysical Union 9(1): 73-74. DOI:10.1029/2011EO 090001.

Grosse G, Jones BM, Arp CD. 2013a. Thermokarst lakes, drainage, and drained basins. In Treatise on Geomorphology, Shroder JF (ed.-in chief), Giardino R, Harbor J (eds). Glacial and Periglacial Geomorphology, San Diego: Academic Press; Vol. 8: 325-353.

Grosse G, Robinson JE, Bryant R, Taylor MD, Harper W, DeMasi A, Kyker-Snowman E, Veremeeva A, Schirrmeister L, Harden J. 2013b. Distribution of late Pleistocene icerich syngenetic permafrost of the Yedoma Suite in east and central Siberia, Russia. US Geological Survey Open File Report 2013-1078.

Havel JE, Hebert PDN, Delorme LD. 1990. Genetics of sexual Ostracoda from a low Arctic site. Journal of Evolutionary Biology 3: $65-84$

Hinkel KM, Jones BM, Eisner WR, Cuomo CJ, Beck RA, Frohn R. 2007. Methods to assess natural and anthropogenic thaw lake drainage on the western Arctic coastal plain of northern Alaska. Journal of Geophysical Research 112: F02S16. DOI:10.1029/ 2006JF000584.

Hinzman LD, Bettez ND, Bolton WR, Chapin FS III, Dyurgerov MB, Fastie CL, Griffith B, Hollister RD, Hope A, Huntington HP, Jensen AM, Jia GJ, Jorgenson T, Kane DL, Klein DR, Kofinas G, Lynch AH, Lloyd AH, McGuire AD, Nelson FE, Nolan M, Oechel WC, Osterkamp TE, Racine $\mathrm{CH}$, Romanovsky VE, Stone RS, Stow DA, Sturm M, Tweedie CE, Vourlitis GL, Walker MD, Walker DA, Webber PJ, Welker JM, Winker KS, Yoshikawa K. 2005. Evidence and implications of recent climate change in northern Alaska and other Arctic regions. Climatic Change 72: 251-298.

Höfle C, Ping CL. 1996. Properties and soil development of late-Pleistocene paleosols from Seward Peninsula, northwest Alaska. Geoderma 71: 219-243.

Höfle C, Edwards ME, Hopkins DM, Mann DH, Ping CL. 2000. The full-glacial environment of the northern Seward Peninsula, Alaska, reconstructed from the 21,500 year old Kitluk paleosol. Quaternary Research 53: 143-153. DOI:10. 1006/qres.1999.2097.

Hopkins DM. 1959. History of Imuruk Lake, Seward Peninsula, Alaska. Geological Society of America Bulletin 70: 1033-1046.

Hopkins DM. 1963. Geology of the Imuruk Lake Area, Seward Peninsula, Alaska. US Geological Survey Bulletin 1141-C: $101 \mathrm{pp}$.

Hopkins DM. 1967. The Bering Land Bridge. Stanford University Press: Stanford, California.

Hopkins DM. 1988. The Espenberg Maars: A record of explosive volcanic activity in the Devil Mountain-Cape Espenberg area, Seward Peninsula, Alaska. In The Bering 
Land Bridge: An Archeological Survey, Schaaf J (ed). US Park Service: 188-247.

Hopkins DM, Kidd JG. 1988. Thaw lake sediments and sedimentary environments. In $5^{\text {th }}$ International Permafrost Conference. Tapir: Trondheim; 790-795.

Hopkins DM, Giterman RE, Matthews JV Jr. 1976. Interstadial mammoth remains and associated pollen and insect fossils, Kotzebue Sound area, northwestern Alaska. Geology 4: 169-172.

Hunt JB, Hill PG. 1996. An inter-laboratory comparison of the electron probe microanalysis of glass geochemistry. Quaternary International 34-36: 229-241.

Hunt S, Yu Z, Jones M. 2013. Lateglacial and Holocene climate, disturbance and permafrost peatland dynamics on the Seward Peninsula, western Alaska. Quaternary Science Reviews 63: 42-58.

Jones BM, Arp CD. 2015. Observing a catastrophic thermokarst lake drainage in northern Alaska. Permafrost and Periglacial Processes. DOI: 10.1002/ppp.1842.

Jones BM, Grosse G, Arp CD, Jones MC, Walter Anthony KM, Romanovsky VE. 2011. Modern thermokarst lake dynamics in the continuous permafrost zone, northern Seward Peninsula, Alaska. Journal of Geophysical Research 116: G00M03. DOI:10. 1029/2011JG001666.

Jones MC, Grosse G, Jones BM, Walter Anthony KM. 2012. Peat accumulation in drained thermokarst lake basins in continuous, ice-rich permafrost, northern Seward Peninsula, Alaska. Journal of Geophysical Research 117: G00M07. DOI:10.1029/ 2011JG001766.

Jordan JW, Mason OK. 1999. A 5000 year record of intertidal peat stratigraphy and sea level change from northwest Alaska. Quaternary International 60: 37-47.

Jorgenson MT, Shur Y. 2007. Evolution of lakes and basins in northern Alaska and discussion of the thaw lake cycle. Journal of Geophysical Research 112: F02S17. DOI: 10.1029/2006JF000531.

Jorgenson MT, Shur YL, Pullman ER. 2006. Abrupt increase in permafrost degradation in Arctic Alaska. Geophysical Research Letters 33: L02503. DOI:10.1029/2005G L024960.

Jorgenson MT, Yoshikawa K, Kanevskiy M, Shur YL, Romanovsky V, Marchenko S, Grosse G, Brown J, Jones B. 2008. Permafrost characteristics of Alaska. In Proceedings of the Ninth International Conference on Permafrost, Kane D, Hinkel K (eds). University of Alaska: Fairbanks; 121-122.

Kanevskiy M, Shur Y, Fortier D, Jorgenson MT, Stephani E. 2011. Cryostratigraphy of late Pleistocene syngenetic permafrost (yedoma) in northern Alaska, Itkillik River exposure. Quaternary Research 75: 584-596. DOI:10.1016/j.yqres.2010.12.003.

Kanevskiy M, Jorgenson T, Shur Y, O'Donnell JA, Harden JW, Zhuang Q, Fortier D. 2014. Cryostratigraphy and Permafrost Evolution in the Lacustrine Lowlands of West-Central Alaska. Permafrost and Periglacial Processes 25: 14-34. DOI: $10.1002 / p p p .1800$

Kaplina TN, Lozhkin AV. 1979. Age of alass deposits of Yakutian coastal lowlands. I $z \mathrm{v}$ RAS Geology 2: 69-76.

Kaufman DS, Hopkins DM. 1986. Glacial history of the Seward Peninsula. In Glaciation in Alaska: The Geologic Record, Hamilton TD, Reed KM, Thorson RM (eds). Alaska Geological Society: Anchorage, Alaska; 51-78.

Kaufman DS, Ager TA, Anderson NJ, Anderson PM, Andrews JT, Bartlein PJ, Brubaker LB, Coats LL, Cwynar LC, Duvall ML, Dyke AS, Edwards ME, Eisner WR, Gajewski K, Geirsdottir A, Hu FS, Jennings AE, Kaplan MR, Kerwin MW, Lozhkin AV, MacDonald GM, Miller GH, Mock CJ, Oswald WW, Otto-Bliesner BL, Porinchu DF, Rühland K, Smol JP, Steig EJ, Wolfe BB. 2004. Holocene thermal maximum in the western Arctic $\left(0-180^{\circ}\right.$ W). Quaternary Science Reviews 23: 529-560.

Kessler MA, Plug LJ, Walter Anthony KM. 2012. Simulating the decadal- to millennial-scale dynamics of morphology and sequestered carbon mobilization of two thermokarst lakes in NW Alaska. Journal of Geophysical Research 117: G00M06. DOI:10.1029/2011JG001796.

Kuehn SC, Froese DG, Shane PAR, Intercomparison Participants (INTAV). 2011. The INTAV intercomparison of electronbeam microanalysis of glass by tephrochronology laboratories: results and recommendations. Quaternary International 246: 19-47.

Kuzmina S, Elias S, Matheus P, Storer JE, Sher A. 2008. Paleoenvironmental reconstruction of the Last Glacial Maximum, inferred from insect fossils from a tephra buried soil at Tempest Lake, Seward Peninsula, Alaska. Palaeogeography, Palaeoclimatology, $\mathrm{Pa}$ laeoecology 267(3-4): 245-255.

Lenz J, Fritz M, Schirrmeister L, Lantuit H, Wooller MJ, Pollard W, Wetterich S. 2013. Periglacial landscape dynamics in the western Canadian Arctic: Results from a thermokarst lake record on a push moraine (Herschel Island, Yukon Territory). Palaeogeography, Palaeoclimatology, Palaeoecology 381-382: 15-25. DOI:10. 1016/j.palaeo.2013.04.009.

Mackay JR. 1997. A full-scale field experiment (1978-1995) on the growth of permafrost by means of lake drainage, western Arctic coast: a discussion of the method and some results. Canadian Journal of Earth Sciences 34: 17-33.

Mackay JR, Burn CR. 2002. The first 20 years (1978-1979 to 1998-1999) of active-layer development, Illisarvik experimental drained lake site, western Arctic coast, Canada. Canadian Journal of Earth Sciences 39(11): 1657-1674.

Mann DH, Peteet DM, Reanier RE, Kunz ML. 2002. Responses of an arctic landscape to Lateglacial and early Holocene climatic changes: the importance of moisture. Quaternary Science Reviews 21: 997-1021.

Marsh P, Russell M, Pohl S, Haywood H, Onclin C. 2009. Changes in thaw lake drainage in the Western Canadian Arctic from 1950 to 2000. Hydrological Processes 23: 145-158.

Matthews JV Jr. 1974. Quaternary environments at Cape Deceit (Seward Peninsula, Alaska) evolution of a tundra ecosystem. Geological Society of America Bulletin 85: 1353-1384.

McCulloch D, Hopkin D. 1966. Evidence for an early recent warm interval in Northwestern Alaska. Geological Society of America Bulletin 77: 1089-1108.

Meisch C. 2000. Freshwater Ostracoda of Western and Central Europe. Spektrum Akademischer Verlag: Heidelberg, Berlin.

Meyers PA. 1994. Preservation of elemental and isotopic source identification of sedimentary organic matter. Chemical Geology 144: 289-302.

Meyers PA, Lallier-Verges E. 1999. Lacustrine sedimentary organic matter records of Late Quaternary paleoclimates. Journal of Paleolimnology 21: 345-372.

Morgenstern A, Ulrich M, Günther F, Roessler S, Fedorova I, Rudaya N, Wetterich S, Boike J, Schirrmeister L. 2013. Evolution of thermokarst in East Siberian ice-rich permafrost: 20 a case study. Geomorphology 201: 363-379. DOI:10.1016/j.geomorph. 2013.07.011.

Munsell Color Company. 1994. Munsell Soil Color Charts. Macbeth Division of Kollmorgen Instruments Corporation: New Windsor, NY.

Murton JB. 1996. Thermokarst-lake-basin sediments, Tuktoyaktuk Coastlands, western arctic Canada. Sedimentology 43: 737-760.

Murton JB, French HM. 1994. Cryostructures in permafrost, Tuktoyaktuk coastlands, western Arctic Canada. Canadian Journal of Earth Sciences 31: 737-747.

Nowacki GJ, Spencer P, Fleming M, Jorgenson T. 2002. Unified ecoregions of Alaska. US Geological Survey Open File Report 02-297. 
Rampton VM. 1988. Quaternary Geology of the Tuktoyaktuk Coastlands, Northwest Territories. Geological Survey of Canada Memoir 423: 98pp.

Regmi P, Grosse G, Jones MJ, Jones BM, Walter Anthony KM. 2012. Characterizing Post-Drainage Succession in Thermokarst Lake Basins on the Seward Peninsula, Alaska with TerraSAR-X Backscatter and Landsat-based NDVI Data. Remote Sensing 4: 3741-3765. DOI:10.3390/rs4123741.

Reimer P, Bard E, Bayliss A, Beck J, Blackwell P, Bronk Ramsey C, Buck C, Cheng $\mathrm{H}$, Edwards R, Friedrich M, Grootes P, Guilderson T, Haflidason H, Hajdas I, Hatté C, Heaton T, Hoffmann D, Hogg A, Hughen K, Kaiser K, Kromer B, Manning S, Niu M, Reimer R, Richards D, Scott E, Southon J, Staff R, Turney C, van der Plicht J. 2013. IntCal13 and Marine13 Radiocarbon Age Calibration Curves 0-50,000 Years cal BP. Radiocarbon 55(4): 1869-1887. DOI: 10.2458/azu_js_rc.55.16947.

Røen U. 1962. Studies on freshwater Entomostraca in Greenland II. Meddr Grønland 170(2): 1-240.

Røen U. 1968. Studies on freshwater Entomostraca in Greenland III. Entomostraca from Peary Land with notes on their biology. Meddr Grønland 184(4): 1-59.

Romanovskii NN. 1993. Fundamentals of Cryogenesis of Lithosphere. Moscow University Press.

Romanovsky VE, Smith S, Christiansen H. 2010. Permafrost thermal state in the polar Northern Hemisphere during the International Polar Year 2007-2009: a synthesis. Permafrost and Periglacial Processes 21: 106-116. DOI:10.1002/ppp.689.

Romanovsky VE, Sazonova TS, Balobaev VT, Shender NI, Sergueev DO. 2007. Past and recent changes in air and permafrost temperatures in eastern Siberia. Global and Planetary Change 56(3-4): 399-413. DOI:10.1016/j.gloplacha.2006. 07.022 .

Rowland JC, Jones CE, Altmann G, Bryan R, Crosby BT, Hinzman LD, Kane DL, Lawrence DM, Mancino A, Marsh P, McNamara JP, Romanvosky VE, Toniolo H, Travis BJ, Trochim E, Wilson CJ, Geernaert GL. 2010. Arctic Landscapes in Transition: Responses to Thawing Permafrost. Eos, Transactions American Geophysical Union 91: 229-230.

Sars GO. 1898. The Cladocera, Copepoda and Ostracoda of the Jana expedition. Annuaire du Musée Zoologique de l'Académie Impériale des Sciences de SaintPétersbourg 3: 324-358.

Schirrmeister L, Meyer H, Wetterich S, Siegert C, Kunitsky VV, Grosse G, Kuznetsova TV, Derevyagin AY. 2008. The Yedoma
Suite of the northeastern Siberian Shelf Region: Characteristics and concept of formation. In Ninth international Conference on Permafrost, Kane DL, Hinkel KM (eds). University of Alaska Fairbanks, Alaska, USA; 1595-1600.

Schirrmeister L, Grosse G, Wetterich S, Overduin PP, Strauss J, Schuur EAG, Hubberten HW. 2011. Fossil organic matter characteristics in permafrost deposits of the northeast Siberian Arctic. Journal of Geophysical Research 116: G00M02. DOI:10. 1029/2011JG001647.

Schirrmeister L, Froese D, Tumskoy V, Grosse G, Wetterich S. 2013. Yedoma: Late Pleistocene Ice-Rich Syngenetic Permafrost of Beringia. In The Encyclopedia of Quaternary Science 3, Elias SA (ed). Amsterdam: Elsevier; 542-552.

Schleusner P, Biskaborn BK, Kienast F, Wolter J, Subetto D, Diekmann B. 2015. Basin evolution and palaeoenvironmental variability of the thermokarst lake El'geneKyuele, Arctic Siberia. Boreas 44: 216-229. DOI: 10.1111/bor.12084.

Schneider A, Wetterich S, Schirrmeister L, Herzschuh U, Meyer H, Pestryakova L. nd. Freshwater ostracods (Crustacea) and environmental variability of polygon tundra in the Indigirka Lowland (northeast Siberia). Polar Research. In press.

Shephard FP. 1954. Nomenclature based on sand-silt-clay ratios. Journal of Sedimentary Petrology 24(3): 151-158.

Smith LC, Sheng Y, MacDonald GM. 2007. A first pan-Arctic assessment of the influence of glaciation, permafrost, topography and peatlands on northern hemisphere lake distribution. Permafrost and Periglacial Processes 18: 201-208. DOI: 10.1002/ppp.581.

Smith SL, Romanovsky VE, Lewkowicz AG, Burn CR, Allard M, Clow GD, Yoshikawa K, Throop J. 2010. Thermal state of permafrostin North America: A contribution to the International Polar Year. Permafrost and Periglacial Processes 21: 117-135. DOI:10.1002/ppp.690.

Soloviev PA. 1962. Alasnyy relyeftsentralnoy Yakutii i yego proiskhozhdeniye (Alas relief in central Yakutia and its origin). In Mnogoletnemerzlyye porody $i$ soputstvuyushehiye irn yavleniy a na territorii Yakutskoy ASSR, Grave NA (ed). Moscow, USSR: Soviet Academy of Science Publishers; 38-53.

Strauss J, Schirrmeister L, Wetterich S, Borchers A, Davydov SP. 2012. Grain-size properties and organic-carbon stock of Yedoma Ice Complex permafrost from the Kolyma lowland, northeastern Siberia. Global Biogeochemical Cycles 26: GB3003. DOI:10.1029/ $2011 \mathrm{~GB} 004104$.

Strauss J, Schirrmeister L, Grosse G, Wetterich S, Ulrich M, Herzschuh U, Hubberten HW.
2013. The deep permafrost carbon pool of the Yedoma region in Siberia and Alaska. Geophysical Research Letters 40: 6165-6170. DOI:10.1002/2013GL058088.

Strauss J, Schirrmeister L, Mangelsdorf K, Eichhorn L, Wetterich S, Herzschuh U. 2014. Organic matter quality of deep permafrost carbon - a study from Arctic Siberia. Biogeosciences Discussions 11: 15945-15989.

Van Everdingen RO (ed). 2005. Multi-Language Glossary of Permafrost and Related Ground-Ice Terms. National Snow and Ice Data Center/World Data Center for Glaciology: Boulder, CO.

Vaughan DG, Comiso JC, Allison I, Carrasco J, Kaser G, Kwok R, Mote P, Murray T, Paul F, Ren J, Rignot E, Solomina O, Steffen K, Zhang T. 2013. Observations: Cryosphere. In Climate Change 2013: The Physical Science Basis. Contribution of Working Group I to the Fifth Assessment Report of the Intergovernmental Panel on Climate Change, Stocker TF, Qin D, Plattner GK, Tignor M, Allen SK, Boschung J, Nauels A, Xia Y, Bex V, Midgley PM (eds). Cambridge University Press: Cambridge and New York.

Walter KM, Zimov SA, Chanton JP, Verbyla D, Chapin FS III. 2006. Methane bubbling from Siberian thaw lakes as a positive feedback to climate warming. Nature 443: 71-75. DOI:10.1038/nature05040.

Walter KM, Edwards ME, Grosse G, Zimov SA, Chapin FS III. 2007. Thermokarst lakes as a source of atmospheric $\mathrm{CH} 4$ during the last deglaciation. Science 318: 633-636.

Walter Anthony KM, Zimov SA, Grosse G, Jones MC, Anthony PM, Chapin FS III, Finlay JC, Mack MC, Davydov S, Frenzel P, Frolking SA. 2014. A shift of thermokarst lakes from carbon sources to sinks during the Holocene epoch. Nature 511: 452-456. DOI:10.1038/nature13560.

Wetterich S, Schirrmeister L, Pietrzeniuk E. 2005. Freshwater ostracodes in Quaternary permafrost deposits in the Siberian Arctic. Journal of Paleolimnology 34: 363-376. DOI:10.1007/s10933-005-5801-y.

Wetterich S, Schirrmeister L, Meyer $\mathrm{H}$, Viehberg FA, Mackensen A. 2008a. Arctic freshwater ostracods from modern periglacial environment in the Lena River Delta (Siberian Arctic, Russia): geochemical applications for palaeoenvironmental reconstructions. Journal of Paleolimnology 39: 427-449.

Wetterich S, Herzschuh U, Meyer $\mathrm{H}$, Pestryakova L, Plessen B, Lopez CML, Schirrmeister L. 2008b. Evaporation effects as reflected in freshwaters and ostracod calcite from modern environments in Central 
and Northeast Yakutia (East Siberia, Russia). Hydrobiologia 614: 171-195.

Wetterich S, Rudaya N, Tumskoy V, Andreev AA, Opel T, Schirrmeister L, Meyer H. 2011. Last Glacial Maximum records in permafrost oft he East Siberian Arctic. Quaternary Science Reviews 30: 3139-3151.

Wetterich S, Grosse G, Schirrmeister L, Andreev AA, Bobrov AA, Kienast F, Bigelow NH, Edwards ME. 2012. Late Quaternary environmental and landscape dynamics revealed by a pingo sequence on the northern Seward Peninsula, Alaska. Quaternary Science Reviews 39: 26-44.

Zimov SE, Schuur EAG, Chapin FS III. 2006. Permafrost and the Global Carbon Budget. Science 312: 1612-1613.

Zona D, Oechel WC, Peterson KM, Clemens RJ, Paw KT, Ustin SL. 2010. Characterization of the carbon fluxes of a vegetated drained lake basin chronosequence on the Alaskan Arctic Coastal Plain. Global Change Biology
16: 1870-1882. DOI:10.1111/j.1365-2486. 2009.02107.x.

\section{SUPPORTING INFORMATION}

Additional supporting information can be found in the online version at the publisher's web site.

Supplementary data are available at http:// dx.doi.org/10.1594/PANGAEA.845556 